\author{
Miłosz SOSNOWSKI \\ https://orcid.org/0000-0002-1517-6979 \\ Uniwersytet im. Adama Mickiewicza w Poznaniu
}

\title{
Święci Wojciech i Brunon z Kwerfurtu w tzw. Legendarium Magdeburgense - utwory hagiograficzne i kalendarz*
}

Zarys treści: Legendarium Magdeburgense (Berlin, Staatsbibliothek zu Berlin, Ms. Magdeb. 26 i 138) to pochodząca z połowy XV w. obszerna dwutomowa kolekcja hagiograficzna. Zawiera ona przeróbkę-skrót stosunkowo rzadkiego żywotu św. Wojciecha (inc. Nascitur) Brunona z Kwerfurtu w redakcji dłuższej (Bibliotheca hagiographica latina [dalej: BHL] 38), wybór z Miracula s. Adalberti (BHL 44, BHL 45), odpis Vita et Passio Brunonis (BHL 1471b, BHL 1472), pasję tzw. Pięciu Braci w wersji Kosmasa (BHL 1148) oraz wypis z epitome kroniki Kosmasa znanej dotąd z jednego zaledwie kodeksu. Artykuł poświęcony jest przede wszystkim kopii pierwszego z tych utworów, jej miejscu w tradycji rękopiśmiennej oraz datowaniu przeróbki. Towarzyszy temu krótka analiza odmianek utworu drugiego oraz uwagi dotyczące pozostałych wymienionych utworów i zapisek kalendarzowych o będących ich bohaterami świętych. W tle poczyniono też uwagi na temat sposobu pracy kompilatorów Legendarium Magdeburgense.

\begin{abstract}
The Legendarium Magdeburgense (Berlin, Staatsbibliothek zu Berlin, Ms. Magdeb. 26 and 138) is a large two-volume hagiographical collection compiled in the mid-fifteenth century. It contains a reworking (abridgement) of the relatively rare longer redaction of the "Second Life" of St. Adalbert of Prague (inc. Nascitur by St. Bruno of Querfurt (Bibliotheca hagiographica latina; hereinafter: BHL 38), a selection from Miracula s. Adalberti (BHL 44, BHL 45), Vita et Passio Brunonis (BHL 1471b, BHL 1472) as well as a passio of Five Brothers (BHL 1148) in a version derived from Cosmas of Prague's chronicle and a short extract from an epitome of Cosmas (the Brunswick epitome known from a single copy). The article focuses on the witness of Nascitur, its place within the manuscript tradition and the dating of the reworking. It is accompanied by a brief analysis of textual readings of Vita et Passio Brunonis and their value vis-à-vis the existing edition, as well as some notes concerning the remaining texts and the calendar entries for those texts' saints. All of the above are supplemented with the remarks focused on Legendarium Magdeburgense compilers' method.
\end{abstract}

Słowa kluczowe: św. Wojciech, św. Brunon-Bonifacy, hagiografia, kult świętych, Magdeburg, krytyka tekstu

Keywords: Adalbert of Prague, Bruno-Boniface of Querfurt, hagiography, cult of saints, Magdeburg, textual criticism

Trzech uczniów szkoły katedralnej w Magdeburgu w drugiej połowie X w. ma kluczowe znaczenie dla naszej znajomości historii Polski pierwszych Piastów. Pierwszym był syn czeskiego książątka znad Cydliny, który zanim został biskupem praskim, a potem „najchwalebniejszym męczennikiem”, wysłany został na nauki do nadłabskiego Miasta Dziewic. Drugim - syn grafa Hassegau, który przed wyborem do elitarnej kapeli cesarza Ottona III, a potem odkryciem w sobie powołania monastycznego,

* Tekst niniejszy powstał w ramach stażu podoktorskiego NCN FUGA 2013/08/S/HS3/00188. Autopsja tytułowych kodeksów w 2016 r. Anonimowym recenzentom artykułu składam serdeczne podziękowania za uwagi, które pozwoliły rozjaśnić wywód oraz uniknąć wielu potknięć. 
misjonarskiego i męczeńskiego, w Magdeburgu nie tylko pobierał nauki, ale również - jak wspominał - podziwiał piękno nadłabskiego krajobrazu. I trzeci wreszcie, kuzyn wyżej wymienionego, z którym siedział w jednej ławie szkolnej, los zaprowadził go nie tak daleko geograficznie i mentalnie jak dwóch pozostałych, ale został on biskupem pogranicznego Merseburga. Ci trzej to oczywiście Wojciech - Adalbert, Bruno - Bonifacy oraz Thietmar. Przez szkolne progi, pod opiekę (i rózgę!) mistrza Oktryka, a potem Geddona ${ }^{1}$, przeszło więc trzech adeptów, z których w przyszłości dwóch stało się świętymi męczennikami, a dwóch misjonarzami, jeden został arcybiskupem, a dwóch biskupami, na koniec wreszcie jeden zasłynął jako hagiograf, a jeden jako kronikarz.

Szkoła katedralna musiała być dumna ze swoich wychowanków i domyślać się trzeba, że - przynajmniej początkowo - pielęgnowano pamięć o nich i zabiegano o dzieła ich dotyczące czy też przez nich napisane ${ }^{2}$. Biblioteka katedralna w Magdeburgu została jednak zniszczona w wielkim pożarze $\mathrm{w} 1449 \mathrm{r}^{3}$ - to zapewne powód, dla którego na próżno szukać tam świadectw rękopiśmiennych utworów Brunona. Pożar ten spowodował konieczność przygotowania nowego zestawu ksiąg, zarówno liturgicznych, jak komemoratywnych - w celu (od)budowania pamięci instytucjonalnej katedry i jej szkoły. Takie odbudowywanie pamięci zawsze jest do pewnego stopnia tworzeniem jej na nowo z przetrwałych, odnalezionych i sprowadzonych - zawsze jednak ponownie interpretowanych - fragmentów.

Zachowanym świadectwem takich czynności zdaje się być przechowywane w Bibliotece Państwowej w Berlinie pod sygnaturami Ms. Magdeb. 26 oraz 138 tzw. Legendarium Magdeburgense, odpowiednio część letnia i zimowa. Po II wojnie światowej jako zdobycz kodeksy wywiezione zostały z gimnazjum katedralnego w Magdeburgu (Domgymnasium Magdeburg) do Związku Radzieckiego, skąd wróciły dopiero w 1961 r., już do Biblioteki Narodowej NRD (Deutsche Staatsbibliothek) ${ }^{4}$. Podobnie jak wielu innym późnośredniowiecznym kolekcjom hagiograficznym, również tej nie poświęcono zbyt wiele uwagi $^{5}$, ale dzięki szczegółowemu katalogowi autorstwa Ursuli Winter znamy obecnie jej zawartość ${ }^{6}$. Legendarium jako świadectwo rękopiśmienne zawartych w nim tekstów powoli wchodzi do obiegu?

Obydwa kodeksy powstać miały w podobnym czasie - część letnia datowana jest precyzyjnie na 1459 r., zimowa zaś spisana zostać mogła tylko niewiele później ${ }^{8}$. Kolofon zawierający datowanie (Ms. Magdeb. 26, f. 423vb) informuje też, że kolekcja skompilowana została z różnych źródeł, choć sądzić można, że domyślnie chodzi tu o pasjonały9. Dwutomowy legendarz magdeburski skompilowany

${ }^{1}$ Zob. Das Erzbistum Magdeburg, t. 1: Das Domstift St. Moritz in Magdeburg, oprac. G. Wentz, G. Schwineköper, Germania Sacra AF, t. 1, cz. 1, Berlin-New York 1972, s. 369-370. Między Oktrykiem a Geddonem szkołą kierował Ekkehard Rudy, ale żadna $\mathrm{z}$ trzech omawianych postaci nie wyszła spod jego kurateli.

${ }^{2}$ Niewykluczone, że Żywot św. Wojciecha w dłuższej, starszej z zachowanych redakcji, pisał Brunon częściowo podczas pobytu w tym mieście w oczekiwaniu na sakrę arcybiskupią (krótko J. Karwasińska, Wstęp, w: MPH s.n., t. 4, cz. 2, Warszawa 1969, s. VII, XX, XXIV). Pasja zaś Benedykta i Jana (zw. Żywotem Pięciu Braci) zachowała się tylko w jednym rękopisie, który wykazuje związki z Magdeburgiem (tak już odkrywca tekstu Reinhard Kade we wstępie do wydania w MHG SS, t. 15 , cz. 2, Hannoverae 1888, s. 711)

${ }^{3}$ Zob. Die Manuscripta Magdeburgica der Staatsbibliothek zu Berlin Preussischer Kulturbesitz, oprac. U. Winter, t. 1, Wiesbaden 2001, s. 7; zob. też P.G. Schmidt, Lateinische Literatur Magdeburgs von ottonischer zu staufischer Zeit, w: Der Magdeburger Dom. Ottonische Gründung und staufischer Neubau, red. E. Ullmann, Lepzig 1989, s. 220-221.

${ }^{4}$ Die Manuscripta Magdeburgica, t. 1, s. 7 nn.

${ }^{5}$ Opracowanie syntetyczne, dość zwięzłe jednak, biorąc pod uwagę rozmiary tomów legendarza i liczbę zawartych w nich tekstów, dała U. Winter, Das Legendarium Magdeburgense in der Staatsbibliothek zu Berlin - Preussischer Kulturbesitz (Mss. Magdeb. 26 und 138), w: Scrinium Berolinense. Tilo Brandis zum 65. Geburtstag, t. 1, red. P.J. Becker, E. Bliembach, H. Nickel, R. Schipke, G. Staccioli, Berlin 2000, s. 320-327.

${ }^{6}$ Die Manuscripta Magdeburgica, t. 1, s. 86-100; tamże, t. 2, oprac. U. Winter, K. Heydeck, Wiesbaden 2004, s. 118-140.

${ }^{7}$ L. Jiroušková, Der heilige Wikingerkönig Olav Haraldsson und sein hagiographisches Dossier. Text und Kontext der Passio Olavi (mit kritischer Edition), t. 1, Mittellateinische Studien und Texte, t. 46, Leiden-Boston 2014, s. 612-614; S. Albrecht, Drei neue Handschriften des sog. Chronicon hungarico-polonicum, St. Źródł., 53, 2015, s. 111-121 oraz w wersji angielskiej tenże, Three New Manuscripts of the so Called [sic!] Chronicon hungaro-polonicum, w: Hungaro-Polonica. Young Scholars on Medieval Polish-Hungarian Relations, red. D. Bagi, G. Barabás, Z. Máté, Pécs 2016, s. 119-141.

8 Die Manuscripta Magdeburgica, t. 1, s. 99.

9 „Et sic est finis huius prime partis collecti ex diuersis passionalis”; zob. Die Manuscripta Magdeburgica, t. 1, s. 99. Ex diversis w domyśle passionalibus, choć nie można wykluczyć, że źródłem były kodeksy rozmaitej natury. Tak rozumieją 
został więc zaledwie 10 lat po pożarze. Czuć pośpiech piszących go rąk. Dwa imponujące rozmiarami i obszerną zawartością tomy zapisane są w dwóch kolumnach wieloma rękami, gęstą, szybką i często nieprzejrzystą bastardą. Niedbałe lub niesystematyczne ostrzenie narzędzia pisarskiego co rusz sprawia, że pismo rozmywa się, a skryba, jakby w pośpiechu, naprawia swe narzędzie nie po kilku rozmytych słowach, lecz dopiero po zapisaniu nim połowy, a nawet więcej strony. Dodatkowym problemem jest system skrótów, który nawet w ramach jednego tekstu nie jest jednolity. Znaczony czerwonym atramentem podział wielokrotnie złożonych zdań (okresów) na mniejsze jednostki składniowe bywa zbyt obfity i wówczas nie tylko nie pomaga w czytaniu, lecz czasem je wręcz utrudnia. Wilhelm Schum, który korzystał z kodeksu zawierającego pars aestivalis przy edycji Gesta archiepiscoporum Magdeburgensium, stwierdził, że kodeks „multis scatet mendis”"10, z czym należy się zgodzić, choć oczywiście jakość kopii zależy też od wysiłków poszczególnych skrybów. Praca kompilatorska była wszak gigantyczna $-z$ różnych innych, nieznanych nam kodeksów (pasjonałów i zapewne innych) dobierano teksty o świętych, którym przypisywano odpowiednią datę (lub daty) w kalendarzu. Zadbano przy tym również o skopiowanie tekstu dotyczącego wydarzenia fundamentalnego dla diecezji, czyli sprowadzenia relikwii do Magdeburga za Ottona ${ }^{11}$. Choć, jak podkreśliła Lenka Jiroušková ${ }^{12}$, brak twardego dowodu na powstanie legendarza dla katedry w Magdeburgu lub w jej skryptorium, to pewne jego cechy (włączenie Denotatio reliquiarum, zawartość, powstanie wkrótce po pożarze), a przede wszystkim - na co zwróciła uwagę U. Winter - kalendarz (zob. dalej) jasno taki stan rzeczy sugerują. Teksty zapisano często w postaci skrótu i przeróbki - ale czy te były dziełem kompilatorów w połowie XV w., czy może już w takiej, znanej nam z Legendarium, postaci zapisane były w podstawie rękopiśmiennej kompilacji - tego nie wiemy i każdy przypadek wymaga osobnej uwagi. Pewien porządek wśród tej mieszaniny wpływów wprowadziła U. Winter, identyfikując teksty pochodzące ze Złotej legendy, martyrologiów Adona i Usuarda, Speculum historiale Wincentego z Beauvais oraz zaginionego Legendarium Halberstadense $^{13}$. Wskazano ostatnio również na Pragę, lub szerzej Czechy, jako na miejsce, skąd twórcy legendarza zaczerpnęli część tekstów ${ }^{14}$, ale moim zdaniem są to wpływy co najwyżej pośrednie (zob. dalej). Jeżeli chodzi o metodę pracy kompilatorów, to trudno zakładać, że każdy z tekstów traktowali (skracali i ewentualnie uzupełniali) w ten sam sposób. Każdy przykład wymaga osobnego pod tym względem rozpatrzenia, podobnie jak potencjalne źródła zdobycia antygrafów ${ }^{15}$ - są to jednak problemy istotne, gdy do pytania o kształt XV-wiecznej magdeburskiej tradycji o świętych Wojciechu i Brunonie dołączymy pytanie o czas powstania tej tradycji w zachowanej w Legendarium formie.

$* * *$

Analiza Legendarium Magdeburgense jako całości wymagałaby wieloletniej pracy ${ }^{16}$, ale dalej zwrócę uwagę zaledwie na trzy teksty, które mogą być interesujące zwłaszcza dla polskiego czytelnika ${ }^{17}$. Jeden

treść kolofonu również: U. Winter, Das Legendarium Magdeburgense; O. Zwierlein, Die Urfassungen der Martyria Polycarpi et Pionii und das Corpus Polycarpianum, t. 1, Berlin-Boston 2014, s. 177. W każdym razie zbyt pospieszne jest zdanie W. Schuma (Gesta archiepiscoporum Magdeburgensium, wyd. W. Schum, w: MGH SS, t. 14, Hannoverae 1883, s. 373), który przy przywołanej edycji korzystał z Legendarium Magdeburgense, że kodeks tu omawiany był po prostu kopią zachowanego tylko fragmentarycznie rękopisu oznaczonego syglem B4 (Staatsbibliothek zu Berlin, sygn. Ms. Boruss. 866 - non vidi) - aczkolwiek może to dotyczyć samego tekstu Gesta archiepiscoporum Magdeburgensium.

${ }^{10}$ W. Schum, [Wstęp], w: Gesta archiepiscoporum Magdeburgensium, s. 373; w nomenklaturze W. Schuma nasz kodeks ma sygiel B4a

${ }^{11}$ Zob. Die Manuscripta Magdeburgica, t. 1, s. 93; A. Mentzel-Reuters, Literaturbericht Handschriftenkataloge, „Deutsches Archiv", 60, 2004, nr 1, s. 219. Tekst Denotatio Reliquiarum w wersji krótszej wydał Harry Breslau, w: MGH SS, t. 30, cz. 2, Lipsiae 1934, s. 956-957.

12 Zob. L. Jiroušková, Der heilige Wikingerkönig, s. 612.

13 Die Manuscripta Magdeburgica, t. 1, s. 87.

${ }_{14}$ S. Albrecht, Three New Manuscripts, s. 127.

${ }^{15}$ W przypadku Passio Olavi droga tekstu do magdeburskiego legendarza ze Szwecji miałaby się odbyć, nieco upraszczając sprawę, za pośrednictwem Gryfii i konwentów franciszkańskich; zob. L. Jiroušková, Der heilige Wikingerkönig, s. 666-668.

${ }^{16}$ U. Winter doliczyła się ponad 400 świąt na każdy z tomów; zob. taż, Das Legendarium Magdeburgense, s. 322.

17 Sygnalizuję szczególnie zwięzłe potraktowanie przeze mnie poniżej pasji tzw. Pięciu Braci w wersji Kosmasa (BHL 1148), którą legendarium zachowuje w przeróbce; zob. Die Manuscripta Magdeburgica, t. 2, s. 137. 
z nich, w części letniej (Ms. Magdeb. 26, f. 313ra-314va), to skrócony i przerabiany - zapewne na miejscu, w Magdeburgu, o czym za chwilę - przekaz żywota Nascitur pióra Brunona z Kwerfurtu, wedle katalogu U. Winter $\mathrm{w}$ redakcji krótszej ${ }^{18}$. $\mathrm{Z}$ katalogu dowiemy się też, że $\mathrm{w}$ tomie zimowym (Ms. Magdeb. 138) na f. 154vb-157ra ${ }^{19}$ znajduje się Translatio $s$. Adalberti, która po bliższym przyjrzeniu się okazuje się wyciagiem z Miracula s. Adalberti, wydanych jak dotąd najpełniej przez Wojciecha Kętrzyńskiego (od rozdz. $3^{20}$ ). Na marginesie fragmentu dotyczącego pielgrzymki Ottona III do Gniezna czerwonym atramentem dopisano uwagę (f. 156va) „lege hanc historiam”, co świadczy o dużym zainteresowaniu kopisty, ale być może również szerzej środowiska XV-wiecznego Magdeburga. Trzeci zaś tekst, ponownie w części letniej (f. 372rb-373vb), to późnośredniowieczny Żywot i pasja św. Brunona-Bonifacego (BHL 1471b) w wersji - jak zapowiada katalog U. Winter - odmiennej od edycji Heinricha Kauffmanna. Pasja Brunona opisana jest w części kalendarzowej rękopisu jako Brunonis translacio. Z kolei na marginesie f. $215 \mathrm{rb}$, na początku żywota biskupa Walentego (BHL 8460), a więc pod datą 14 lutego, znajduje się wzmianka niebieskim atramentem: „Eodem die sancti Brunonis de Quernforde”.

Wśród liczniejszych zapewne innych „poloników” zwróciłem uwagę na Ms. Magdeb. 26, f. IIr, gdzie pod kalendarzem wśród wielu sporządzonych czerwonym atramentem zapisek mnemotechnicznych, historycznych i przysłów widnieje chronostych „Ulric bella fecit polonis ipse magister Mo CCCCo Xo"²1.

\section{Kalendarz legendarza}

Kalendarz zawarty w Ms. Magdeb. 26 (listopad-czerwiec) i 138 (lipiec-listopad) rejestruje wielką liczbę świąt, również tych o znaczeniu ściśle lokalnym, i wyraźnie wskazuje na Magdeburg jako miejsce powstania kolekcji ${ }^{22}$. Jednocześnie podkreślić należy, że nie jest to kalendarz liturgiczny, z definicji zawierający wiele dni pustych ${ }^{23}$, lecz kalendarz kompletny, z każdym dniem wypełnionym co najmniej jednym świętym. Kompletność kalendarza sugeruje też, że święta weń zawarte przynależeć mogą do obcej tradycji (niekoniecznie jednak mechanicznie skopiowanej) i dopiero w drugiej połowie XV w. m.in. $\mathrm{z}$ tego legendarza (?) dokonywano selekcji świąt do miejscowego kalendarza liturgicznego. $\mathrm{Z}$ punktu widzenia tego artykułu interesujące są daty, do których przypisano wspomnienia Wojciecha oraz Brunona. Pomijam zaś datę, pod jaką wpisanych zostało tzw. Pięciu Braci - 12 listopada - która jest w zasadzie uniwersalna ${ }^{24}$. Bezpośrednio mają one potencjalnie znaczenie dla historii kultu (ale czy liturgicznego?) obu świętych w XV-wiecznym Magdeburgu. Pośrednio zaś mogą nam powiedzieć coś na temat pochodzenia odpowiednich tekstów zawartych w kolekcji.

Najmniej kontrowersyjny jest oczywiście dies natalis św. Wojciecha - 23 kwietnia ${ }^{25}$, który w Ms. Magdeb. 26. znajdujemy na f. IIIv czarnym atramentem jako Alberti episcopi pragensis obok czerwonym atramentem wpisanego Jerzego (Georrii (!) martyris). Zgodność tej daty ze stosunkowo powszechną praktyką sprawia, że nie musimy poświęcać jej tu miejsca ${ }^{26}$. Bardziej intrygująca jest data translacji

${ }_{18}$ Die Manuscripta Magdeburgica, t. 1, s. 95; chociaż podany numer BHL odpowiada redakcji dłuższej.

19 Rękopiśmienny wykaz świętych zamieszczony po kalendarzu odnosi czytelnika do f. 155; zob. Staatsbibliothek zu Berlin, Ms. Magdeb. 138, f. IVv, gdzie: „Alberti episcopi pragensis translacio 155”.

${ }^{20}$ Miracula sancti Adalberti, wyd. W. Kętrzyński, w: MPH, t. 4, Lwów 1884, s. 228-238.

${ }^{21}$ Staatsbibliothek zu Berlin, Ms. Magdeb. 26, f. IIr; na temat tego chronostychu zob. C. Ochałówna, Bitwa grunwaldzka w poezji polsko-łacińskiej XV wieku, „Małopolskie Studia Historyczne”, 3, 1960, nr 1-2, s. 96, 106.

${ }^{22}$ Manuscripta Magdeburgica, t. 1, s. 87; tamże, t. 2, s. 120.

${ }^{23}$ Kalendarze liturgiczne magdeburskie mamy dopiero z nieco późniejszego okresu, od $1480 \mathrm{r}$. począwszy - ich układ podaje H. Grotefend, Zeitrechnung des Deutschen Mittelalters und der Neuzeit, t. 2, cz. 1, Hannover 1892, s. 109-113.

${ }^{24}$ Staatsbibliothek zu Berlin, Ms. Magdeb. 138, f. IVv, gdzie pod II ydus listopada najpierw widnieje czerwonym atramentem „Livini episcopi et martyris”, potem zaś czarnym: „Quinque fratrum” oraz „Cuniberti episcopi Colonie”. Tylko ten pierwszy odnotowany jest w materiale magdeburskim kalendarzy Grotefenda; tenże, Zeitrechnung. Benedykt i Jan zaś pod inną datą (16 listopada) figurują jedynie w kalendarzu kamedulskim.

${ }^{25}$ Choć święto występuje również w kalendarzach pod 24 (także w Magdeburgu), 22 kwietnia oraz 19 marca w Havelbergu.

${ }^{26}$ Oprócz może tego, że wymienienie świętych tego samego dnia oraz wyraźne pierwszeństwo Jerzego, podobnie jak brak oktawy, nie wykazują tu wpływu diecezji polskich (tak samo było w niezależnym już wówczas od Gniezna biskupstwie 
św. Wojciecha, najpierw wyznaczona w Ms. Magdeb. 138, f. IIIv, gdzie pod VIII kal. Sept. (25 sierpnia) znajdujemy - obydwa wpisy czarnym atramentem - Genesii martyris oraz Alberti episcopi translacio. W samym legendarzu tekst cudów również następuje ze wzmianką eodem die, po św. Genezjuszu (którego festum w diecezji magdeburskiej obchodzono właśnie 25 sierpnia). Jest to więc data zgodna z tradycją czeską, odmienną od tzw. polskiej (20 października) i tzw. węgierskiej (6 listopada). Potem jednak, co komplikuje sprawę, w Ms. Magdeb. 138 na f. IVv pod datą 6 listopada (VIII id.) znajduje się również Alberti episcopi translacio. Obydwie daty przeniesienia - czeska i węgierska - współwystępują więc w tym samym kalendarzu, zapisane tą samą ręką - dominująca jest przy tym data sierpniowa, gdyż zgodnie z nią wpisany został tekst „translacji”.

Rodzi to oczywiście pytanie o pochodzenie takiego datowania translacji. Jak pokazał Wojciech Danielski wszystkie trzy daty wstępują również w materiale „polskich” diecezji: czeską spotykamy we Wrocławiu (materiał od XIV w., ale też od tego stulecia święto bywa przenoszone na 26 sierpnia, co domyka się ok. 1400 r.), Lubuszu (najstarszy materiał z 1490 r., być może pod wpływem wrocławskim) oraz jedno- czy dwukrotnie w Krakowie, przed ustabilizowaniem się daty październikowej ${ }^{27}$. Przypomnieć należy, że w czasie spisania legendarza biskupstwo lubuskie podlegało już, od 1424 r., archidiecezji magdeburskiej. Charakterystyczna data translacji trafić zatem mogła zarówno z Magdeburga do Lubusza, jak i w kierunku odwrotnym. Niekoniecznie świadczy to na rzecz zdobycia tekstu z Czech, Śląska czy Lubusza. Inną wskazówką związaną z datowaniem jest dopisanie na górnym marginesie, przy zakończeniu cudów, krótkiego tekstu dotyczącego translacji św. Wojciecha, tzw. Pięciu Braci oraz Gaudentego do Czech, o czym więcej poniżej.

Wychwyćmy teraz daty związane ze św. Brunonem. W kalendarzu Ms. Magdeb. 26, f. IIIr pod XVI kalendami marca (14 lutego) odnotowano najpierw czerwonym atramentem święto: Valentini presbiteris, a następnie czarnym atramentem: Valentini episcopi oraz: Brunonis episcopi et martyris. Data pozbawiona jest kwalifikatorów, domyślnie oznacza więc dies natalis. Spośród sprzecznych datowań śmierci Brunona pojawiających się w średniowiecznym dziejopisarstwie saskim ${ }^{28}$ obecne tu jest zgodne ze znanym z kroniki Thietmara ${ }^{29}$, które później przejmują Annalista Saxo ${ }^{30}$ i Gesta episcoporum Halberstadensium $^{31}$. Identyczną datę, w dwóch miejscach, przekazuje anonimowy żywot Brunona wydany przez H. Kauffmanna, który jednak w wersji naszego legendarza dodaje w jednym z nich jako alternatywną również datę o dzień późniejszą (,16o quidam putant $15 \mathrm{KL}$ marcii”) ${ }^{32}$. Druga wzmianka w kalendarzu legendarza magdeburskiego znajduje się na f. IVr pod X kal. czerwca (23 maja), gdzie wpisany jest św. Dezyderiusz z Vienne (Desiderii episcopi). Ta sama lub bardzo podobna ręka wpisała ciemniejszym atramentem Brunonis translacio. Koresponduje to z informacją rubryki (na marginesie), jaką opatrzony jest początek żywota Brunona: „Brunonis Tr[anslatio] X KL Junii”. Ta druga data jest niespotykana, podobnie jak w ogóle „translacja” Brunona, i nie potrafię jej wyjaśnić3 ${ }^{33}$.

kamieńskim). O tym i o nielicznych wyjątkach (zwłaszcza Ołomuniec, 22 kwietnia) zob. W. Danielski, Kult św. Wojciecha na ziemiach polskich $w$ świetle przedtrydenckich ksiąg liturgicznych, przyg. do dr. i wstęp J.J. Kopeć CP, Lublin 1997, s. 41-49.

27 Tamże, s. 55, $62 \mathrm{nn}$.

${ }^{28}$ Obszernie E. Kessel, Die Magdeburger Geschichtschreibung im Mittelalter bis zum Ausgang des 12. Jahrhunderts, „Sachsen und Anhalt", 7, 1931, s. 152, 156, passim. Krótkie zebranie wzmianek daje aparat H. Kauffmanna; Vita et passio sancti Brunonis episcopi et martyris Querfordensis, wyd. H. Kauffmann, w: MGH SS, t. 30, cz. 2, Lipsiae 1934, s. 1354, przyp. 2.

29 Thietmari Merseburgensis episcopi Chronicon, wyd. R. Holtzmann, w: MGH, Scriptores rerum Germanicarum, Nova Series, t. 9, Berolini 1935, s. 388, 389.

${ }^{30}$ Dwukrotnie (pod 1009 i 1106 r.), w tym raz w wywodzie genealogicznym Lotara z Supplinburga; zob. Die Reichschronik des Annalista Saxo, wyd. K. Nass, w: MGH SS, t. 37, Hannover 2006, s. 311, 531.

${ }^{31}$ Gesta episcoporum Halberstadensium, wyd. L. Weiland, w: MGH SS, t. 23, Hannoverae 1874, s. 90.

32 Zob. Vita et passio sancti Brunonis, s. 1366. Datę Thietmara ma też obecna w dwóch rękopisach (sygle B3 i B3 ${ }^{\mathrm{a}}$ wg W. Schuma) - nie w naszym - interpolacja redakcji B Gesta archiepiscoporum Magdeburgensium, skądinąd tekstu niedatującego śmierci Brunona; zob. Gesta archiepiscoporum Magdeburgensium, s. 391.

33 Jeszcze inna, i równie odosobniona, jest data śmierci biskupa i męczennika Brunona w zachowanym „Nekrologu mersburskim”, gdzie pod 21 sierpnia zapiska notuje „Brun epc et mr”; podobiznę tej karty kodeksu (Domstiftsbibliothek Merseburg, sygn. Cod. I, 129, f. 5r) zob. Die Totenbücher von Merseburg, Magdeburg und Lüneburg, wyd. G. Althoff, J. Wollasch, w: MGH, Libri memoriales et Necrologia, Nova Series, t. 2, Hannover 1983, s. 11 (wiele osobnych numeracji stron, tu właściwa dla podobizn kodeksu, cytowanego przez wydawców jako Cod. Merseburg. 129). 
Na koniec wspomnieć należy, że zapiski kalendarzowe mają swoje odpowiedniki w indeksie świętych (Ms. Magdeb. 26, f. IVv-VIIv), gdzie na f. Vr figuruje zarówno Wojciech (jednokrotnie jako Alberti episcopi pragensis et martyris), jak i dwukrotnie Brunon, jako Brunonis natiuitas oraz Brunonis translacio.

Daty, pod którymi do legendarza w XV-wiecznym Magdeburgu wpisani są święci - nie mamy oczywiście informacji o randze ewentualnego święta itd., ale wszystkie sporządzone są czarnym atramentem - pokazują, że zarówno Wojciecha, jak i Brunona wspominano potencjalnie dwa razy w roku. Dies natalis obydwu jest standardowy (nawet biorąc pod uwagę różnorodność daty natalicium w źródłach dla Brunona), natomiast dni translacji są mniej oczywiste. W przypadku Wojciecha wskazują na wpływy czeskie albo bezpośrednio, albo drogą lubuską bądź śląską, w przypadku Brunona zaś data wspomnienia jest skądinąd nieznana, przy czym nie bardzo wiadomo, które konkretnie wydarzenie zdaniem kompilatorów legendarza konstytuuje translację, ani skąd i dokąd miałaby się ona odbyć.

\section{Translatio Adalberti}

Rubryka na f. 154vb w Ms. Magdeb. 138 zapowiada Alberti episcopi translacio. Krótko wprowadzony tekst („Eodem die translacio sancti Alberti de quo sic legitur”) rozpoczyna się od słów: „Cum in Ungaria Christum predicaret primo per nunccios suos deinde per se ipsum". Tekst jest czytelniejszy niż w omawianym dalej żywocie Nascitur, litery mniej kursywne, narzędzie pisarskie ostrzone regularnie, pismo z bardziej ustabilizowanym systemem skrótów. Rozpoznajemy tu tzw. Miracula s. Adalberti, a konkretnie początek rozdziału trzeciego wedle numeracji nadanej przez Georga Heinricha Pertza, znanej również z wydania W. Kętrzyńskiego ${ }^{34}$. Rozdział ten skopiowany jest in extenso, z pewnymi drobnymi skrótami i upraszczającymi tekst wariantami, czasem ze zmianą strony czasownika (ale bez zmiany sensu), podobnie jak kolejne, tj. $4^{35}, 5^{36}$ (w którym jednak wbrew innym kopiom występuje naddatek o ostatecznym sukcesie Wojciecha na Pomorzu! $!^{37}$ ) i $6^{38}$. Następny w kolejności rozdział 7 ma nieznany rękopisom W. Kętrzyńskiego dodatek na końcu. Znane z wydań Miracula opowiadają o dwukrotnym ataku Prusów na Wojciecha i dwukrotnym widzeniu ich płonących domostw, jakie zesłał na nich Bóg, po czym przechodzą do cudu o odnalezionym palcu świętego (czyli do rozdz. 8). Tekst cudów oparty jest oczywiście na przekazie legendy Tempore illo, w którym jednak mowa jest również o trzecim, zakończonym śmiercią Wojciecha ataku. W magdeburskim rękopisie po kończącym rozdział 7 „,conseruari illibata ualerent” (tu: „sacrificia compleri ualerent”) następuje opis trzeciego ataku: „Tercio igitur ibidem Pruteni, qui et Summi dicuntur, in eos irrunt; et 7 lanceas in eius corpus figunt; et penetralia cordis eius perforant".

W uzupełnieniu najpierw pobrzmiewa echo Tempore illo (gdzie: „tercio redeunt et in pernitionem ${ }^{39}$ sancti pontificis irreuocabiliter seuientes irruunt") z dodaniem zniekształconej nazwy Sambów (Summi), pojawiającej się w Miracula w rozdz. 2, którego jednak nie ma w kopii zawartej w legendarzu. Dalsza część jest problematyczna. Po pierwsze łatwo zauważyć, że - jak dotąd - w cudach mowa jest o samodzielnej wyprawie Wojciecha do Prus. W naddatku zaś Prusowie rzucają się in eos (nie illum itp.), co sugeruje mechaniczne uzupełnienie z jakiegoś tekstu, w którym Prusowie rzucają się na Wojciecha i towarzyszących mu misjonarzy. Problem z dalszą częścią uzupełnienia wynika również z tego, że w Tempore illo (oraz spożytkowanych przez W. Kętrzyńskiego kopiach Miracula) brak wzmianki

${ }^{34}$ Miracula sancti Adalberti, s. 228; wcześniejszą edycję G.H. Pertza na podstawie jednego rękopisu (Bayerische Staatsbibliothek, Clm 14126) zob. Miracula sancti Adalberti martiris, wyd. G.H. Pertz, w: MGH SS, t. 4, Hannoverae 1841, s. $613-616$.

${ }^{35}$ Między innymi z poprawnie przekazanymi informacjami na temat przedłużonego postu oraz latami jego trwania i datą zniesienia.

${ }^{36}$ Między innymi z poprawnym imieniem Gaudentego, Pomorzem zapisanym zaś raz jako Pomerancia (oprócz tego poprawnie). W rozdziale tym również zapis imienia Adalbertus, zamiast właściwego dla tej magdeburskiej kopii Albertus.

37 „Eos [Pomorzan - M.S.] tamen tandem conuertit”.

${ }^{38}$ Między innymi zapis Prus jako Prucia.

39 pernitione c.; pernitionem corr. edd. 
o siedmiu włóczniach. Inaczej w żywotach najstarszych. Cesarska redakcja Est locus nie jest tu jednoznaczna - mowa jest albo o pojedynczej włóczni, która otwiera siedem ran, albo o włóczniach, które otwierają siedem $\operatorname{ran}^{40}$. W redakcji awentyńskiej zapis zdaje się wskazywać wyjęcie „siódmej” włóczni ${ }^{41}$. Brunon z Kwerfurtu w Nascitur pisze już wprost o siedmiu włóczniach ${ }^{42}$. Podobnie jest w powstałym na podstawie obydwu starszych żywotów utworze In partibus Germaniae ${ }^{43}$. Prawdopodobne jest oczywiście uzupełnienie przekazu za pomocą znajdującego się w drugim tomie legendarza żywotu Nascitur ${ }^{44}$, zwłaszcza że redaktorzy legendarza doskonale zdawali sobie sprawę z relacji tych dwóch tekstów, dając nawet stosowny odnośnik ${ }^{45}$. Sygnalizowany tutaj problem należy zapewne odłożyć do czasu przebadania większej liczby rękopisów In partibus Germaniae (wraz z Miracula).

Po tym naddatku następuje przejście do rozdziału 8 , który jest jednak silniej przerobiony i miejscami skrócony w stosunku do rękopisów spożytkowanych przez W. Kętrzyńskiego. Integralną - podobnie jak w wydaniach drukowanych - jego częścią jest właściwy opis translacji i zjazdu gnieźnieńskiego. Rozpoczynający się od słów „Porro scientes Pruteni” tekst w Legendarium uzupełniony jest o alternatywną nazwę Sambów („Pruteni seu Sammi”). Zamiast Trzemeszna, podobnie jak w rękopisie monachijskim (Bayerische Staatsbibliothek, Clm 14126 = „I” wedle nomenklatury W. Kętrzyńskiego) miejscem, gdzie znajduje się cenobium, w którym spoczęły relikwie Wojciecha, jest Gniezno (Gnezna). Po wykupie zaś relikwii wprowadzona jest dopiero opowieść o odnalezieniu głowy Wojciecha przez szlachetnego Prusa w Sambii (f. 156rb: „Prutenus quidam nobilis ex Pomeraniis causa negociorum uenit in Sammiam Prucie terram”) z drukowanego rozdziału 2 Miracula. W edycji W. Kętrzyńskiego opowieść tę wieńczy informacja o tym, że w miejscu, gdzie Prus pogrzebał głowę świętego niegdyś (olim) stał kościół poświęcony Wojciechowi ${ }^{46}$. W magdeburskim legendarzu zaś kościół przedstawiony jest jako istniejący: „In loco autem, in qua capud sancti martiris gentilis reposuerat est ecclesia in honore eius consecrata, qua una cum loco illo in reuerencia non modica habetur. Illucque multa miracula fieri referuntur" ${ }^{` 4}$. Trudno w tej zmianie domyślać się własnej inwencji kompilatora (choć i wykluczyć tego obecnie nie sposób). Wydaje mi się, że taki już zmieniony tekst odnalazł magdeburski redaktor w swej podstawie, która w tym przypadku najprawdopodobniej byłaby kopią pochodzącą z Warmii albo szerzej $\mathrm{z}$ terenów państwa zakonu krzyżackiego. Bez przebadania tradycji rękopiśmiennej Miracula trudno tu jednak o jednoznaczne wnioski. $\mathrm{W}$ tym miejscu czerwonym atramentem zaznaczony jest nowy akapit, w cudach wydrukowanych kończący rozdział 8 , który opowiada o zagrożeniu relikwii wojnami „inter paganos finitimos et Polonos”, w wyniku czego przeniesione one zostają 6 listopada do Gniezna („,8 ydus nouembris in Gnezen”). Nie chodzi w tym miejscu o głowę - która podobnie jak w relacji wydanych Miracula pozostała w Sambii - ale o relikwie, które przecież już wcześniej - wedle tekstu tego samego legendarza - w Gnieźnie się znalazły.

${ }^{40}$ S. Adalberti Pragensis episcopi et martyris vita prior, wyd. J. Karwasińska, w: MPH s.n., t. 4, cz. 1, Warszawa 1962, s. 46: „extractę hastę septem ingencia uulnera pandunt”. Pierwsza interpretacja zakłada, że extracte hastę to genetivus 1. poj. Wedle drugiej chodzi o mianownik 1. mn. Warto dodać, że zapiska septem w postaci liczby (VII) mogła dawać kopiście zachętę do próby samodzielnego jej rozwiązania w sposób inny niż zamierzony i być przyczyną nieporozumienia, czego dotyczy - włóczni czy ran.

${ }^{41}$ Tamże, s. 66: „extracte aste septime ingencia uulnera pandunt”.

${ }^{42}$ S. Adalberti Pragensis episcopi et martyris vita altera auctore Brunone Querfurtensi, wyd. J. Karwasińska, w: MPH s.n., t. 4, cz. 2, Warszawa 1969 [dalej: VAA], rozdz. 32, s. 37: „septem lanceis pulchra uiscera forant” oraz s. 38: ,in eius honore septem lanceis confossus"; redakcja krótsza ma skróconą relację, ale zawierającą obydwa sformułowania; zob. tamże, s. 68.

${ }^{43}$ Tekst nie ma jak dotąd wydania drukowanego - poniższe informacje opierają są na transkrypcjach 14 rękopisów z wersji roboczej przygotowywanej edycji. W 12 rękopisach: „Septem autem magnis uulneribus confossus de lanceis”. W 2 innych kopiach: „S. a. m. de lanceis uulneribus confossus”. Kilka zdań wcześniej: „lictor ferus [...] iaculum ingens uibrans transfixit eius penetralia cordis" ( $\mathrm{z}$ wariacją szyku w materiale rękopiśmiennym).

${ }^{44}$ Staatsbibliothek zu Berlin, Ms. Magdeb. 26, f. 314va: „Albertus [...] septem lanceis [sic!] a barbaris in corpus acceppit [...]. Primus nefarie cohortis perforat penetralia eius cordis; Inde ceteri in eum manus funestas iniciunt cum lanceis et scelus peragunt".

45 Zob. tamże, f. 314va przy końcu Nascitur po informacjach o wykupieniu relikwii: „de quo plenius in eius translatione patebit”.

${ }^{46}$ Miracula sancti Adalberti, w: MPH, t. 4, s. 228.

${ }^{47}$ Staatsbibliothek zu Berlin, Ms. Magdeb. 138, f. 156va. 
Kolejny w rękopisie znak akapitu z czerwonym dopiskiem marginalnym („lege hanc historiam”) wyznacza fragment tożsamy z rozdziałem 9 drukowanych Miracula. Tekst nie ma większych odmian od podanego przez W. Kętrzyńskiego. Zwraca uwagę podkreślona od razu tożsamość Ottona („Otto 3us imperator”) oraz brak określenia miejsca koronacji (w części rękopisów Miracula: „in monasterio Gneznensi"). Fragmentu opiewającego Bolesława Chrobrego oraz informującego o braku po dziś dzień królów w Polsce nie ma (od „Iste rex Polonorum” do „in Polonia non surrexit”).

Spośród wykorzystanych przez W. Kętrzyńskiego rękopisów tekst - mimo pewnych skrótów, zmian szyku i zastępowania słów bliskoznacznymi - najbliższy zdaje się świadkowi „I” (zob. wyżej), czyli XIV-wiecznej kopii, jednego ze starszych świadków tekstu, której jednak W. Kętrzyński nie widział i znał ją tylko z wydania G.H. Pertza, które posłużyło mu za podstawę. Przykłady przywołuję w przypisie ${ }^{48}$, wskazując tu tylko, że w ogóle tzw. Miracula Adalberti domagają się nowej edycji, oczywiście wraz żywotem In partibus Germaniae, z którym w materiale rękopiśmiennym zwykle tworzą jedną całość ${ }^{49}$. Przeróbka zawarta w magdeburskim legendarzu powinna być dla tych celów również wykorzystana.

\section{Cronica Boemorum z Brunszwiku jako źródło uzupełnień Translacji}

Brązowym i łatwiej blaknącym atramentem - inną ręką, ale współcześnie pisaniu legendarza - na marginesie górnym Ms. Magdeb. 138, f. 157r dopisane zostało krótkie uzupełnienie translacji Wojciecha. Oto w 1040 r., po śmierci Kazimierza (Odnowiciela), książę Brzetysław, wykorzystując fakt, że Bolesław (Szczodry) i Władysław (Herman) byli jeszcze dziećmi, najechał Polskę, Kraków obrócił w perzynę, a z kościoła NMP w Gnieźnie zabrał ciało św. Wojciecha do kościoła św. Wita w Pradze, w którym niegdyś tenże święty rezydował jako biskup. Dopisek głosi też, że oprócz Wojciecha zabrał książę z Gniezna do Pragi ciało jego brata i arcybiskupa gnieźnieńskiego, świętego Gaudentego oraz ciała Pięciu Braci. Wszystkie te relikwie zaś zostały czcigodnie przyjęte w dniu św. Bartłomieja (24 sierpnia).

Wbrew pozorom dopisek ten nie jest autorskim (tzn. naszego kompilatora) skrótem odpowiednich fragmentów kroniki Kosmasa ${ }^{50}$. Jednobrzmiący tekst odnajdujemy bowiem w tzw. Cronica Boemorum, wyciągu z Kosmasa oraz jego kontynuatorów, doprowadzonym do 1278 r., jaki odnalazł niegdyś Oswald Holder-Egger w rękopisie w Trewirze (obecnie Trewir, Stadtbibliothek, nr 1999/129 8). Kodeks go przechowujący, datowany na początek XIV w., jest odpisem kolekcji historycznej powstałej ok. 1294-1296 r., której autorem miał być nieznany bliżej kanonik katedry św. Błażeja w Brunszwiku ${ }^{51}$. Dotychczas rękopis trewirski był jedyną znaną kopią omawianej epitome Kosmasa ${ }^{52}$. W legendarzu magdeburskim

${ }^{48}$ Zestawienie brzmienia wybranych wspólnych lekcji Ms. Magdeb. 138 i Clm 14126 przeciw brzmieniu tekstu głównego W. Kętrzyńskiego w rozdz. 7: indigni pagani-indigene pagi, reperiunt-reperierunt; w rozdz. 8: compares uestri similibus - comparibus uestris similes; w rozdz. 9: ullo modo - nullum, piis patris - patris, subito penitus - subito, munificenciis magnificenciis, esse consortem imperii - consortem imperii esse, suo - proprio, desunt - in monasterio Gneznensi. Przekaz bliski jest też rękopisowi II W. Kętrzyńskiego (XV-wieczny rękopis z kościoła Mariackiego w Gdańsku, Biblioteka Gdańska PAN, Ms. Mar F 202). Te dwa przekazy, wraz z kilkoma innymi (Uppsala, Universitetsbiblioteket, C 520 oraz C 281; Paris, Bibliothèque nationale de France, Lat 8432), tworzą jedną z dwóch podstawowych linii tradycji rękopiśmiennej In partibus Germaniae (tego zagadnienia dotyczy przygotowywany przeze mnie artykuł).

${ }^{49} \mathrm{O}$ tym XIII-wiecznym utworze, najpopularniejszym żywocie św. Wojciecha w Polsce średniowiecznej, najszerzej jak dotąd zob. W. Drelicharz, Idea zjednoczenia królestwa w średniowiecznym dziejopisarstwie polskim, Monografie Towarzystwa Naukowego Societas Vistulana, t. 1, Kraków 2012, s. 243-246; P. Węcowski, Początki Polski w pamięci historycznej późnego średniowiecza, Monografie Towarzystwa Naukowego Societas Vistulana, t. 2, Kraków 2014, s. 74-82.

${ }^{50}$ Cosmae Pragensis Chronica Boemorum, wyd. B. Bretholz, w: MGH, Scriptores rerum Germanicarum, Nova Series, t. 2, Berolini 1923, ks. 2, rozdz. 2-3 i 5, s. 80-84, 90-91.

${ }^{51}$ K. Nass, Zur Cronica Saxonum und verwandten Braunschweiger Werken, „Deutsches Archiv für Erforschung des Mittelalters", 49, 1993, nr 2, s. 557 nn.; O. Holder-Egger, Über die Braunschweiger und Sächsische Fürstenchronik und verwandte Quellen, „Neues Archiv”, 17, 1892, s. 159 nn.

52 M. Bláhová, Cronica Boemorum auctore canonico S. Blasii Brunsvicensi, w: Encyclopedia of the Medieval Chronicle, red. G. Dunphy, Leiden-Boston $2010<\mathrm{http} / /$ referenceworks.brillonline.com/entries/encyclopedia-of-the-medieval-chronicle/ cronica-boemorum-auctore-canonico-s-blasii-brunsvicensi-SIM_001041> [dostęp: 10.11.2017]. 
oprócz różnicy w dacie rocznej i nieco innego zapisu nazw własnych mamy tekst niemal identyczny w stosunku do trewirskiego odpisu brunszwickiej kolekcji:

Ms. Magdeb. 138, f. $157 \mathrm{r}$

Anno $\mathrm{M}^{\circ} 40^{\circ}$ Kazimir dux Polonie moritur et filiis eius Bolislao et Wedislao adhuc infantibus,

Braczeslaus Poloniam uastauit, Krakouiam euertit, ab ecclesia sancte Marie in Gnezen corpus sancti martiris et pontificis Alberti abstulit et in ecclesiam sancti Uiti Prage, in qua episcopus fuerat, honorifice collocauit.

Corpus eciam archiepiscopi Gnezensis sancti Gaudenci, fratris sancti Alberti et corpora $5^{\mathrm{e}}$ fratrum de Gnezen in Pragam transmisit;

que in die sancti Bartolomei uenerabiliter sunt recepti [!].
MGH SS, t. 30, cz. 1, Hannoverae 1896, s. $38^{53}$

Tempore illo Kazimir duce Polonie defuncto, et filiis eius Bolilzlao et Wadizlao adhuc infantibus,

Bracezlaus Poloniam vastavit, Crakoviam evertit, ab ecclesia sancte Marie in Gnezden corpus sancti martyris atque pontificis abstulit Adelberti et in ecclesiam sancti Viti Prage, in qua episcopus erat, honorifice collocavit.

Corpus eciam archiepiscopi Gnezdensis Gaudencii, fratris sancti Adelberti, et corpora quinque fratrum de Gnezden in Pragam transtulit;

que reliquie in die sancti Bartolomei in Praga venerabiliter sunt suscepte anno Domini MXXXIX.

Oznacza to, że kompilatorzy legendarza w Magdeburgu albo mieli w ręku bezpośrednio kodeks trewirski, albo jego zaginioną brunszwicką podstawę, albo jeszcze inny zaginiony odpis. Zwrócić trzeba uwagę, że omawiana wzmianka o translacji do Pragi z oznaczeniem dnia, kiedy miała ona miejsce (in die sancti Bartolomei $=24$ sierpnia) służyć mogłaby za element datujący dla kalendarza w magdeburskim legendarzu, ale jest o jeden dzień przesunięta względem zawartej tam daty. Wbrew pozorom więc $\mathrm{w}$ tym przypadku źródłem tak tekstu, jak i być może datowania, nie są bezpośrednio Czechy, lecz tradycja uprzednio przetworzona, a pochodząca, jak się zdaje, z Brunszwiku, z przełomu XIII i XIV w.

Podobnie jest zresztą w przypadku zawartej w tomie letnim magdeburskiego legendarza ${ }^{54}$ relacji Kosmasa o Pięciu Braciach ${ }^{55}$. Tekst ten, mimo dużej liczby zachowujących go rękopisów, jest słabo znany i nie został wydany osobno, porównywanie lekcji nie ma zatem większego sensu. Wersja legendarza zawiera interesujące naddatki, jak np. dość długi passus egzegetyczny rozpoczynający się oraz zakończony porównaniem Pięciu Braci do pięciu wróbli z Ewangelii Łukasza (Łk 12, 6-8) i w nawiązaniu do Orygenesa interpretujący liczbę $5 \mathrm{w}$ kontekście pięciu zmysłów. Naddatkiem pokazującym intertekstualność metody pracy kompilatorów jest fragment o przekazaniu Pięciu Braciom pieniędzy przez władcę (tu przez Mieszka II): „Unde in uita eorum scribitur, cum dux Mescho filius Boleslay quem tercius Otto de duce in regem Polonie coronauit, uti in translacione Alberti - eis centum marcas misit, stupefacti dixerunt: Est laqueus mortis argenti pondus et auri...". Nie tylko więc kompilatorzy skracają zastany tekst, ale również uzupełniają go informacjami czerpanymi z utworu o innym świętym, tj. translacji (Miracula) św. Wojciecha. Na końcu tekstu znajduje się informacja o losie relikwii: „,orpus sancti Cristini in ecclesia et ciuitate Luthmolicz, 4or autem aliorum in Praga cum maximo honore seruantur et recoluntur". Nazwa miejscowości, w której znalazło się ciało Krystyna, to dalekie przekształcenie nazwy Ołomuńca. Tak dalekie, że trudno sobie wyobrazić je w kopii powstałej na terenie $\mathrm{Czech}^{56}$. Wydaje się więc, że podstawa legendarza miała w tym miejscu już zepsutą lekcję - nie była to więc podstawa czeska. Odsuwa to - podobnie jak brunszwickie pochodzenie omówionego tu naddatku o translacji Wojciecha - domysły o czeskim pochodzeniu pewnych partii legendarza ${ }^{57}$. Owszem, w pierwotnej wersji są to teksty pochodzenia czeskiego (kronika Kosmasa), ale ich wersje wciągnięte, po obróbce, do legendarza z Czech zdają się nie pochodzić.

\footnotetext{
${ }^{53}$ O. Holder-Egger konsekwentnie używa w edycji błędnej sygnatury (nr 1199), ale chodzi o ten sam kodeks.

${ }^{54}$ Staatsbibliothek zu Berlin, Ms. Magdeb. 138 f. 368va-369rb.

${ }_{55}$ Cosmae Pragensis Chronica Boemorum, ks. 1, rozdz. 38, s. 68-72.

${ }^{56}$ Podobnej formy zapisu nie odnotowują L. Hosák, R. Šrámek, Místni jména na Moravě a ve Slezsku, t. 2, Praha 1980, s. $173-178$.

57 Tak sugeruje S. Albrecht, Three New Manuscripts, s. 127.
} 


\section{Vita Brunonis}

Wśród utworów hagiograficznych poświęconych Brunonowi z Kwerfurtu niejasne jest miejsce tzw. Vita et Passio Brunonis (BHL 1471b i 1472). Wydane zostały stosunkowo późno, najpierw staraniem Heinricha Gisberta Voigta w 1927 r. ${ }^{58}$, w 1934 r. zaś przez H. Kauffmanna w szeroko dostępnej podserii Scriptores wydawnictwa wielotomowego Monumenta Germaniae historica. Ten ostatni zwrócił uwagę, za W. Schumem, na wzmiankę w legendarzu, że żywot Brunona znajdować miał się w drugiej części pasjonału ${ }^{59}$. Wiedział więc o istnieniu pars hiemalis legendarza magdeburskiego (sygiel B4a, za W. Schumem), ale odpis weń zawarty uznawał za zaginiony („quod non iam exstare dolemus”) ${ }^{60}$. Oparł się w swej edycji, podobnie jak przedtem H.G. Voigt, na tzw. Memorabilia Querfurtensia, pochodzącym z XVI w. kodeksie z nieistniejącego dziś archiwum miejskiego w Kwerfurcie (sygn. A 45). Dla części drugiej, czyli passio, korzystał H. Kauffmann również z drukowanego brewiarza halbersztadzkiego z 1515 r., którego tekst przedrukował poprzedni wydawca pasji - Augustyn Kolberg.

$\mathrm{Na}$ marginesie Ms. Magdeb. 26, f. 215rb, obok rubryki pasji Walentego, niebieskim atramentem, ręką właściwą dla tej partii legendarza, dopisano: „Eodem die sancti Brunonis de Qwerforde, require in eius translacione ante Urbani”. Zgodnie z tym dopiero na f. 372rb opatrzony rubryką „Brunonis Tr[anslatio] IX Kal. Junii” rozpoczyna się tekst, poprzedzony jeszcze uwagą datacyjno-organizacyjną: „Brunonis translacio cuius festi obitus celebratur die Ualentini siue $16 \mathrm{kal}$. marcii ibi defalcatus hic uero repetitur". Kompilatorzy znali więc datę zgodną z podaną przez Thietmara (14 lutego), ale pominięty wówczas (na f. 215rb) tekst (ibi defalcatus) przenieśli, zgodnie z uznawaną przez siebie datą translacji, tutaj (hic repetitur). Jest to data o dzień późniejsza od wspomnianego w kalendarzu święta Brunonis translacio wpisanego w kalendarzu - jak pamiętamy - pod X Kal. Iun.

Załączenie kompletnej listy lekcji i dokładne zestawianie wydania z przekazem zawartym w Legendarium byłoby niepraktyczne ze względu na zbyt daleko idące skróty i przeróbki. Ogólnie rzecz biorąc tekst jest krótszy niż wersja wydana drukiem, ale zawiera pewne naddatki i różnice, które odnosić się mogą do lepszej podstawy, niż rękopis wykorzystany przez H. Kauffmanna. Z nazw własnych identyczne są imiona rodziców (w legendarium: „Pater eius Bruno, mater uero Ida nomine”), nazwa rzeki, do której poganie wrzucili głowę męczennika (,eius caput in flumen quod Alstra dicitur proiecerunt”61). Inaczej natomiast oddane jest imię władcy, który skazuje męczennika na śmierć (Seboden zamiast Zebeden). Nauki szkolne Brunona, podobnie jak w tekście wydanym przez H. Kauffmanna, umieszczone są w Halberstadt - dopiero kolejny etap ma miejsce w Magdeburgu.

Spośród naddatków zwróćmy uwagę na ten w opowieści o zimowej wizycie Brunona w teatrze. W tekście wydanym nie bardzo wiadomo, dlaczego bohater się tam znalazł. Tu czytamy, że został: „adhuc iuuenis per socios suos ad theatrum pro considerando choreas et huiusmodi adductus". W rękopisie wykorzystanym przez H. Kauffmanna opowieść koncentruje się wokół bosych stóp Brunona, który nie tylko znosi wytrwale zimno, ale też cudownie rozgrzewa posłanego po niego sługę. Tekst niby wspomina o oczach wzniesionych ku niebu, a opowieść podsumowana jest refleksją o tym, ile warta jest w oczach Boga wytrwała modlitwa, ale widoczne jest, że czegoś tu brakuje. Tutaj wprowadzona zostaje symetria między towarzyszami zajętymi sprawami próżnymi (,ceteris gaudenter circa uanitates occupatis”) a Brunonem zajętym sprawami niebiańskimi (,,ipse interim cum superis occupatus”), między oglądaniem występu doczesnego („,mundanis hiis uanitatibus”) a Brunonem zapatrzonym w występ niebiańskich dziewic („,quis [sic!] ceptus choreis uirginum celestium et ibi »pascere inter lilia« ut cantat de virginibus ecclesia"). Tekst jest na pewno nieco zepsuty - np. w hymnie Iesu, corona virginum, do

\footnotetext{
${ }^{58}$ H.G. Voigt, Eine neuerdings wiederentdeckte mittelalterliche Lebensbeschreibung des Preußenmissionars Brun von Querfurt, „Sachsen und Anhalt”, 3, 1927, s. 87-134 (edycja s. 126-134).

${ }^{59}$ Oprócz tej również o innych w piśmiennictwie magdeburskim wzmiankach zob. Vita et passio sancti Brunonis, s. 1350, przyp. 1, który wymienia „sicut indicat liber eius veraci relatione conscriptus”, „sicut passionis eius refert historia” oraz „cuius vita patet in prima parte (huius) passionalis”.

${ }^{60}$ Tamże, s. 1359, przyp. 15.

${ }^{61}$ proicierunt $\mathrm{c}$.
} 
którego nawiązuje, jest: „qui pascis inter lilia | saeptus [zamiast ceptus - M.S.] choreis virginum”62 ale wydaje się oddawać starszą, a na pewno pełniejszą wersję. Dalej, postać sługi w wydanym tekście wprowadzona jest w sposób niejasny: „Venit itaque servus [poprawione przez H.G. Voigta z rkps. A: suus - M.S.] missus a parentibus nimisque frigore trementi [rkps A: trementibus - M.S.] assistens verba parentum, uti iussis fuerat, loquebatur”. W Legendarium jest to jaśniejsze: „Sic occupato uenit seruus missus ad eum a parentibus, cereales apportando ex nimio frigore trementibus membris, uerba parentum, uti in comisso ${ }^{63}$ habuit, loquebatur". W obydwu opowieściach chodzi więc o coś innego. W tekście wydanym trzęsie się z zimna Brunon (a bez koniektury na trementi tekst w ogóle jest tu bez sensu), choć cała puenta jest przecież taka, że kontemplacja i modlitwa utrzymywały go w cieple. W wersji Legendarium trzęsą się z zimna dłonie sługi, który z rozkazu rodziców przynosi Brunonowi pieczywo i przekazać ma mu kilka słów. W obydwu wersjach sługa zostanie rozgrzany dzięki gorącej modlitwie, ale tylko w wersji legendarza składa się to na spójną opowieść. Dodatków jest więcej, m.in. o ochrzczeniu przez Brunona dziewięciorga dzieci kobiety należącej do jego rodu, o pochodzeniu nazwy źródełka fons Brunonis, ale nie sposób wszystkich ich tu omówić.

Dochodzą do tego odmianki szczegółowe, które w legendarzu są dowodnie lepsze, w tym takie, których domyślali się wydawcy, emendując zastany w swym rękopisie tekst. Podajmy tylko jeden przykład. W tekście wydanym przez H. Kauffmanna znajdujemy porównanie wracającego do Magdeburga Brunona: „quasi ovis argumentata”, które w legendarzu oddane jest jako „quasi ovis argumentosa”. Wydawca domyślał się, że może to być aluzja lub cytat, ale nie był w stanie wskazać jego źródła ${ }^{64}$. Jest nim albo późnoantyczna Pasja św. Cecylii ${ }^{65}$, albo późniejsze responsorium do oficjum tej świętej - w obu przypadkach Cecylia, owieczka Chrystusa (w niektórych rękopisach zaś apis, pszczółka) określona jest jako argumentosa ${ }^{66}$.

Jak już wspomniano, Ms. Magdeb. 26 zawiera również, począwszy od f. 424va, jeden z odpisów Gesta archiepiscoporum Magdeburgensium, w której to kopii - jak odnotował już wydawca W. Schum, który nadał temu rękopisowi sygiel B4a - po słowach „martirio coronatus est in confinio Rucie et Litue regionum” widnieje obiecująca informacja „cuius vita patet in prima parte huius passionalis”. W związku z tym, że w innych przekazach rękopiśmiennych Gesta archipiscoporum Magdeburgensium widnieje nieco podobne określenie „sicut indicat liber gestorum eius”, można by przypuszczać, że zaginionym liber gestorum jest tekst przekazany przez legendarz magdeburski. Jednak dokładny rozbiór zapisek redakcji rękopiśmiennych Gesta archipiscoporum Magdeburgensium w kontekście opowieści o Brunonie i poświęconym mu Liber gestorum przeprowadzony ostatnio przez Ingę Leonavičiūtè ${ }^{67}$ wyklucza taką możliwośćc8 .

${ }^{62}$ Antiphonale Romanum secundum liturgiam horarum ordinemque cantus officii dispositum a Solesmensibus monachis praeparatum, t. 2: Liber Hymnarius cum invitatoriis et aliquibus responsoriis, Solesmes 1983, s. 310.

${ }_{63} \bar{\imath} 9 \bar{l} s s o$ c.

${ }^{64}$ Vita et passio sancti Brunonis, s. 1362, przyp. 1.

${ }^{65} \mathrm{H}$. Delehaye, Étude sur le légendier romain. Les saints de novembre et de décembre, Subsidia Hagiographica, t. 23, Brussels 1936, s. 198.

${ }^{66}$ Warianty zob. Corpus Antiphonalium Officii, red. R.-J. Hesbert, t. 4, Roma 1970, s. 127 (nr 6498); por. też bazę Cantus, $<$ http://cantusindex.org $>$, id: 001747.

${ }^{67}$ I. Leonavičiūtè, Magdeburgo arkivyskupu darbai. Šv. Brunono Kverfurtiečio Darbu knygos (Liber Gestorum) klausimas, „Lietuvos istorijos studijos”, 35, 2015, s. 9-23. Włącznie z legendarzem magdeburskim, choć chyba bez autopsji świadka.

${ }^{68} \mathrm{Na}$ ile rozpoznajemy go w zachowanych przeróbkach, pierwotny tekst Vita et Passio Brunonis był bardziej typowym tekstem hagiograficznym - lubującym się z opisywaniu oznak świętości, w niewielkim stopniu interesującym się polityką i światem doczesnym. Jednocześnie nie był to tekst wczesny jak relacja Wiperta (BHL 1417) czy Thietmara. Spisany zapewne w diecezji halbersztadzkiej (może w Kwerfurcie), gdy pokolenie ludzi pamiętających Brunona żywego już zmarło (a więc najwcześniej w drugiej połowie XI w.) - świadczy o tym podkreślanie halbersztadzkiego wątku w jego życiu, a minimalizowanie ukochanego Magdeburga. Bolesław Chrobry z dobroczyńcy, jakim jest u Thietmara, staje się pogańskim księciem, nawróconym dopiero dzięki cudom dokonywanym przez Brunona (taka przemiana też bardziej spodziewana jest w Halberstadt niż w Magdeburgu). Żywot i pasja Brunona zdecydowanie jawią się przede wszystkim jako wyraz kultu. Jako obraz świętego atlety zawierają co prawda pewne szczegóły świadczące o sile pamięci środowiska (imiona rodziców, nazwy własne w ogóle, wydarzenia z młodości i z czasu, gdy Bruno nie wyjechał jeszcze z Saksonii na zawsze), ale są one przetworzone zgodnie ze sztuką hagiograficzną. 
Podsumowując, należy podkreślić, że przekaz Vita oraz Passio Brunona zawarte w magdeburskim legendarzu mimo swej niedoskonałości stanowią nieodzowny punkt odniesienia dla ewentualnych dalszych studiów nad kwestiami krytycznotekstowymi.

\section{Żywot św. Wojciecha Nascitur}

Jako ostatni omówię tu utwór, który ze względu na przygotowywaną przeze mnie nową edycję interesuje mnie najbardziej, czyli żywot Nascitur św. Wojciecha pióra Brunona z Kwerfurtu, który w Ms. Magdeb. 26 znajduje się na f. 313ra-314va.

Pisany w ciągu tekst podzielony został na czternaście części, bardzo nierównej objętości, sygnalizowanych sporządzonymi czerwonym atramentem znakami akapitu, które są jedynymi oznakami podziału wewnętrznego oprócz otwierającego tekst niebieskiego inicjału pisanego E(odem die). Te czternaście części obejmuje opowieści: 1) od narodzin Wojciecha do jego powrotu z Magdeburga do Pragi, 2) od śmierci biskupa czeskiego (niewymienionego z imienia Dytmara) do napomnienia Ottona (II) przez św. Wawrzyńca, 3) od wezwania Wojciecha przez cesarzową Teofano do pierwszego powrotu do Pragi, 4) obszerny opis wydarzeń wokół cudzołożnicy i prób udzielenia jej azylu aż po powtórny wyjazd do Rzymu, 5) cud niestłuczonego naczynia, 6) uzdrowienie ślepej, 7) uzdrowienie człowieka, który nie mógł jeść chleba od trzech lat, 8) dictum Wojciecha w drodze do Rawenny, 9) przyjazd Wojciecha do Magdeburga i rozmowa z kobietą wspominającą jego młodość, 10) kłótnia Astryka z Wojciechem i ukaranie go przez Boga, 11) opowieść o obdarowaniu ubogiej wdowy, 12) wydarzenia od przyjazdu Ottona III do Rzymu aż po śmierć braci Wojciecha, 13) wypadki od wysłania poselstwa do Bolesława po śmierć Wojciecha, 14) ujawnienie przez Ducha Świętego wieści o śmierci Wojciecha pewnemu prezbiterowi oraz wykupienie głowy i ciała (ze wzmianką: „,de quo plenius in eius translatione patebit”). Niektóre z tych akapitów składają się z od jednego do kilku zdań $(5-9,14)$, inne natomiast są obszerniejsze.

$\mathrm{Na}$ jednym krańcu spektrum metod zastosowanych przy redagowaniu żywota Nascitur w legendarzu magdeburskim znajduje się intensywne skracanie. Zobrazujmy je na słowach rozpoczynających rozdział 1:

\begin{tabular}{|l|l|}
\hline $\begin{array}{l}\text { Żywot Nascitur, rozdz. 1 (za: MPH s.n., t. 4, cz. 2, s. 3- } \\
\text { podkreślono słowa pominięte) }\end{array}$ & Ms. Magdeb. 26, f. 313ra \\
\hline $\begin{array}{l}\text { Nascitur purpureus flos Boemicis terris, } \\
\text { maior filius ex parentibus magnis aureum pomum processit } \\
\underline{\underline{\text { e nobilibus ramis. Progreditur pulcra facie, sed pulcrior spiritu }}}\end{array}$ & $\begin{array}{l}\text { Nascitur purpureus flos bohemicis terris, } \\
\text { ex magnis parentibus, }\end{array}$ \\
$\begin{array}{l}\text { Wogitihc puerulus, } \\
\text { quod nomen interpretatum sonat consolatio exercitus. }\end{array}$ & $\begin{array}{l}\text { nomine Wogitech, } \\
\text { quod sonat consolatio exercitus. }\end{array}$ \\
\hline $\begin{array}{l}\text { Pater eius erat uir magnus et prepotens, substantia eius integra, } \\
\text { possessio diffusa. Est ei mortalium felicitatum copia, sub }\end{array}$ & Pater eius \\
$\begin{array}{l}\underline{\underline{\text { se positorum hominum unda, familia multa perstrepens, }}} \\
\underline{\underline{\text { argento et auro plena domus. Cum esset dominus terrę fuit }}}\end{array}$ & domen mediocris homo, oratio rara, sed habitauerat secum \\
$\underline{\underline{\text { misericordia bona, neglecta castitas, et larga pauperum cura. }}}$ & mater eius ex genere slauorum. Ambo boni. \\
\hline Mater ex genere Sclauorum
\end{tabular}

Zwraca uwagę dążenie do zachowania warstwy informacyjnej przy jednoczesnej eliminacji kunsztownych i rozbudowanych sformułowań, które podobnie jak bliższa charakterystyka rodziców Wojciecha uznane widocznie zostały za niepotrzebne (nie chodzi tylko o będace w pierwotnym tekście nieprzychylne uwagi o ojcu bohatera, bo pozytywne też zostały usunięte). Uproszczono również szyk zdania. W części poświęconej słowiańskiemu imieniu świętego zdecydowano się na pominięcie nomen interpretatum, jakby zostawiając je domyślne. Taka postać tekstu, aczkolwiek wejść musi do wykorzystanej w edycji tradycji rękopiśmiennej, jest zwykle mało użyteczna. Z punktu widzenia restytucji tekstu wersja w magdeburskim legendarzu bywa jeszcze mniej przydatna, gdyż czasami skrót idzie nawet 
dalej. Składający się z kilku zdań opis dziecięcej choroby Wojciecha sprowadzony został tu do: „Natus hic puer cepit infirmari”, podobnie jak kunsztowne - i różnorodne przynajmniej w świadectwach rękopiśmiennych redakcji krótszej - w wersji pierwotnej wprowadzenie osoby Henryka II (,qui tangit reges linea sanguinis, quem longe lateque iura dantem hodie tremunt populi, Henrico regi accessit proximus nepos” ${ }^{69}$ ) tu zastąpione jest krótkim: „Hic [tj. ojciec Wojciecha - M.S.] nepos Henrici imperatoris”.

Liczne są jednak też fragmenty, które mimo że skracane, pozwalają wszak posiłkować się lekcjami pozostawionymi przez kompilatorów legendarza. Przykładem niech będzie komentarz do spełnienia się proroczego snu Wojciecha, gdy wszyscy jego bracia zginęli. Porównajmy świadectwa obydwu redakcji. Ponieważ nie zaobserwowano kontaminacji między rękopisami poszczególnych redakcji, możliwe jest wykorzystanie lekcji w miejscach kontrowersyjnych (podkreślono lekcje zmienne w tradycji obydwu redakcji - sygle świadków zgodne z edycją J. Karwasińskiej).

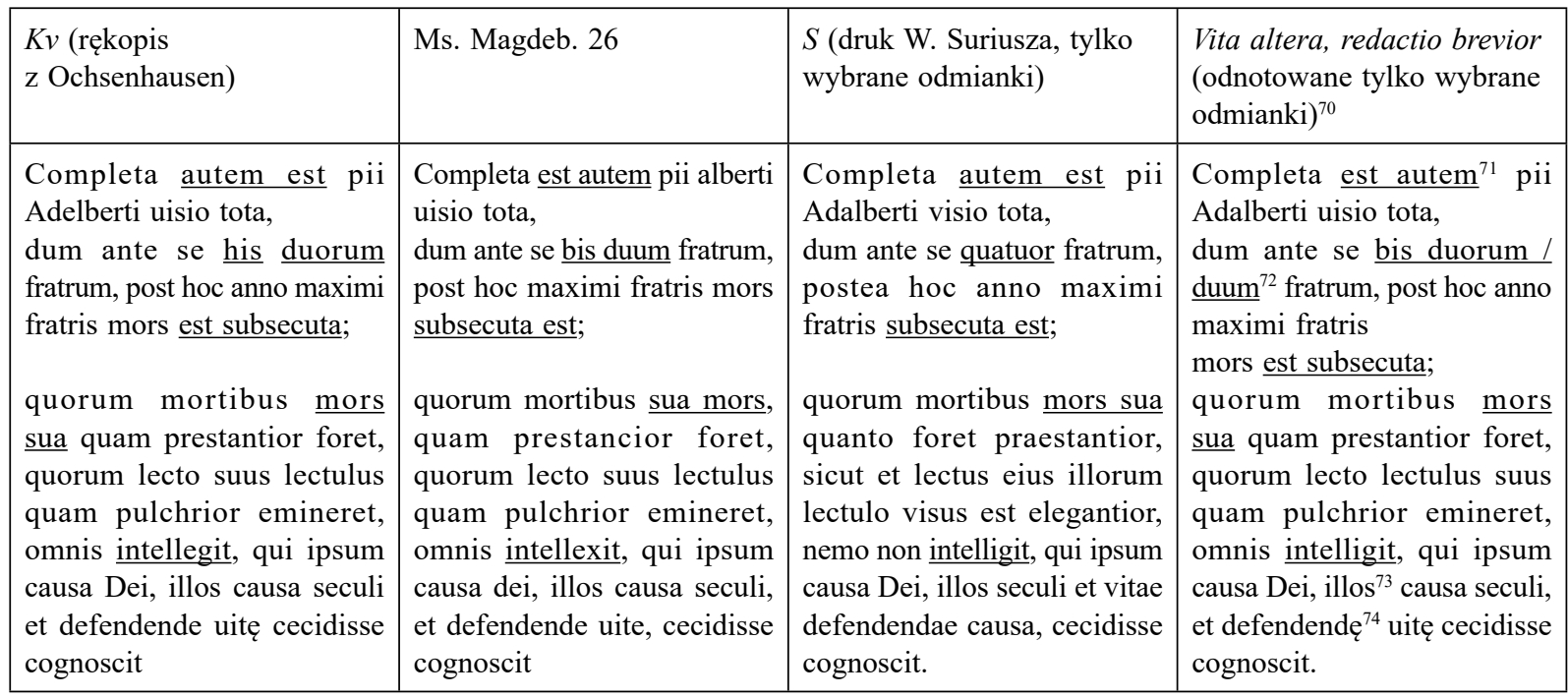

Dość drugorzędne kwestie kolejności słów pomijamy tutaj na rzecz odmianek istotnych. Tam gdzie dotychczas w lekcjach świadectw redakcji dłuższej brakowało bis duorum (ew. duum), teraz potwierdzenie daje nam legendarz magdeburski. $Z$ drugiej strony wprowadzenie czasu przeszłego (intellexit) - jakby w próbie uzgodnienia czasu z dalszą częścią zdania (gdzie cognoscit) - zamiast widocznego w pozostałych świadkach czasu teraźniejszego należy odrzucić, gdyż Brunon zwraca się do współczesnego sobie czytelnika.

Najbardziej dla nas fortunną metodą redaktorów, na drugim krańcu wspomnianego spektrum metod, było pozostawianie zastanego przekazu, $\mathrm{z}$ ewentualnymi drobnymi zmianami. $\mathrm{W}$ całości przekazane zostały pewne budujące zdarzenia, które możemy zestawiać z przekazami innych świadectw. Jako przykład weźmy powtórzoną in extenso opowieść o dobroczynności Wojciecha względem ubogiej wdowy. Obecność w przekazie tego fragmentu, pominiętego w redakcji krótszej, upewnia nas, że mamy do czynienia nie z przeróbką redakcji krótszej - co sugeruje U. Winter ${ }^{75}$ - a redakcji dłuższej, znanej Jadwidze Karwasińskiej ze świadectwa rękopiśmiennego $(K v)$ i druku Wawrzyńca Suriusza $(S)$, opartego na innej

${ }^{69}$ VAA, rozdz. 1, s. 3 (dla różnorodności lekcji wersji krótszej zob. tamże, s. 45).

70 VAA, rozdz. 21, s. 60.

${ }^{71}$ Brak w rkps. czeskich.

${ }^{72}$ duorum $A b, A d 3$; duum rell. codd. r.b.

${ }^{73}$ Brak w $A b$, Ad3; ita rell. codd. r.b.

${ }^{74}$ defendente w rkps. czeskich red. krótszej.

${ }^{75}$ U. Winter, Das Legendarium Magdeburgense, s. 323, przyp. 28, gdzie podaje numer BHL 39 (red. krótsza) i odnosi czytelnika do wydania G.H. Pertza w MGH (czyli red. krótszej na podstawie rękopisu Ad3), ale również do wydania redakcji dłuższej w edycji J. Karwasińskiej, na co wskazuje zakres stron. 
niż $K v$ podstawie. Wskazują na to również inne elementy. Charakterystyczną zmianą różnicującą jest napis na tkaninie we śnie Wojciecha w brzmieniu redakcji dłuższej „Munus hoc donat tibi filia” (tak też w Ms. Magdeb. 26), w rękopisach redakcji krótszej zaś „Munus hoc autentum donat tibi filia regis”76. Świadczą o tym również odmianki bardzo drobne. Ojciec Wojciecha określony jest jako pater suus w redakcji krótszej, w dłuższej zaś pater eius ${ }^{77}$. W ten sposób również najpełniejszy przekaz $K v$ otrzymuje potwierdzenie w miejscach, które moglibyśmy uważać za poprawki własne kopisty (lub jego poprzednika).

Do świadków, którymi dysponowała J. Karwasińska $(K v, S)$, należy wobec tego dodać odkryty przez Klausa Nassa ${ }^{78}$, błędnie jednak przeanalizowany ${ }^{79}$, fragmentaryczny odpis zachowany w makulaturze w Wolfenbüttel (Niedersächsisches Landesarchiv, Staatsarchiv Wolfenbüttel, 12 Slg $11 \mathrm{nr}$ 8; nadamy mu sygiel $W t$ ) oraz, obecnie, rękopis magdeburski.

Przyjrzyjmy się więc zapowiedzianej relacji o Wojciechu odziewającym wdowę, zestawiając przekaz $K v$ (zachowane karty $W t$ go nie zawierają) i skrót magdeburski. Dalej zajmiemy się tym fragmentem w druku $S$.

\begin{tabular}{|c|c|}
\hline $\begin{array}{l}\text { Nascitur według } K v \text {, f. } 150 \mathrm{r} \text { (podkreślono słowa pominięte } \\
\text { w odpisie Ms. Magdeb. 26): }\end{array}$ & $\begin{array}{l}\text { Ms. Magdeb. 26, f. 313vb: (czcionką pogrubioną oznaczono } \\
\text { słowa zmienione względem } K v \text { ) }\end{array}$ \\
\hline $\begin{array}{l}\text { Similiter uidua quędam occurrens equitanti, cum nudę penurię } \\
\text { aliquam consolationem quęreret; mecum hic nichil habeo, } \\
\text { inquid, } \\
\text { cras ueni ad ciuitatem, sumens a me tuę necessitati, quę dare } \\
\text { ualeo cum caritate. } \\
\text { Cumque dimissa muliere cępto itineri insisteret, quem melior } \\
\text { cogitatio tetigit, } \\
\text { uocans mulierem episcopus dixit: } \\
\text { Quis scit, si usque mane uiuamus? Hodie compleat acceptio } \\
\text { datum, } \\
\text { ne ego iudicium ulla sentiat damnum. } \\
\text { Et data cappa, qua amictus erat, reliquid exemplum bonum. } \\
\text { Opus non tardet, nescientibus quid futura pariat dies. }\end{array}$ & $\begin{array}{l}\text { Similiter uidua occurens equitanti, misere penurie aliquam } \\
\text { consolacionem quereret, mecum hic nil habeo, inquit, } \\
\text { cras ueni ad ciuitatem, sumens a me tue necessitati, que dare } \\
\text { ualeo cum caritate. } \\
\text { Cumque dimissa muliere, cepto itineri insisteret, quem melior } \\
\text { cogitatio tetigit, } \\
\text { dixit episcopus: uoca mulierem, } \\
\text { quis scit si usque mane uiuamus. Hodie compleat accepcio } \\
\text { datum, } \\
\text { ne ego iudicium, illa sensiat dampnum; } \\
\text { et data cappa qua amictus erat, reliquit exemplum bonum. } \\
\text { Opus non tardet, nescientibus quid futura pariat dies. }\end{array}$ \\
\hline
\end{tabular}

Pomięte zostały słowa uznane za niepotrzebne, jak quędam, czy być może uznane za domyślne cum. Przekształcenia hic nihil w hoc nil (bardzo zresztą nieczytelne w Ms. Magdeb. 26) jest również drugorzędne, podobnie jak sentiat $\mathrm{w}$ błędne sensiat. Zmiana damnum $\mathrm{w}$ dampnum jest tylko ortograficzna, obrazowe zaś nude penurie zastąpiono dość bliskim misere penurie. Oprócz pomyłek i różnic wynikających z kopiowania ad sensum zamiast ad litteram generalnie widać więc niemal identyczność tekstu magdeburskiego z przekazem $K v$.

Wyjątkiem jest jednak zdanie rozpoczynające się od cumque dimissa, a kończące na damnum. Zostawiwszy wdowę z pustymi rękami i udawszy się w dalszą drogę, Wojciech zmienia zdanie (a dosłownie dotyka go melior cogitatio). W tym miejscu świadectwo obydwu rękopisów jest rozbieżne. Wedle kopii $K v$ „wołając kobietę, biskup mówi: »Kto wie, czy«”, po czym wygłasza, jakby do niej, refleksję na temat upływu czasu i ryzyka niespełnienia od razu dobrych uczynków. Wedle kopii magdeburskiej „biskup mówi »zawołaj kobietę! Kto wie czy«”. Sprawę komplikuje fakt, że identyczny jak kopia magdeburska przekaz ma w tym miejscu druk W. Suriusza ${ }^{80}$, oparty wszak na jakiejś dawniejszej kopii. Mówi

76 VAA, rozdz. 20, s. 26, 58.

77 VAA, rozdz. 1, s. 3, 45.

${ }^{78}$ K. Nass, Wolfenbütteler Funde, „Deutsches Archiv für Erforschung des Mittelalters”, 49, 1993, nr 1, s. 165-169.

79 Autor zamiast zestawić brzmienie odkrytego przez siebie rękopisu z brzmieniem $K v$ i $S$, ograniczył się do zestawienia z tekstem głównym edycji J. Karwasińskiej. Ten ostatni jest jednak kompilowany z brzmienia $K v$ (wiodącego), druku $S$ oraz nierzadko z rękopisów redakcji krótszej; szczegółowo zob. M. Sosnowski, Studia nad wczesnymi żywotami św. Wojciecha. Tradycja rękopiśmienna i polemika środowisk, Poznań 2013, s. 73-78.

${ }^{80} \mathrm{~S}$, wedle wydania pierwszego De probatis sanctorum historiis [etc.], t. 2 (martii et aprilis), wyd. L. Surius, Coloniae Agrippinae 1571, s. 834. 
nam to tyle, że fragment ten nie został poddany w tym miejscu korekcie stylistycznej przez Suriusza, lecz najprawdopodobniej taką lekcję zastał on w swojej podstawie, podobnie jak redaktor magdeburski. Jest to zmiana stosunkowo daleko idąca, między Wojciechem samodzielnie wołającym kobietę i wygłaszającym mowę do niej a jadącym dalej i każącym jakiemuś swemu towarzyszowi, świadkowi tych wydarzeń, ją przywołać (uoca mulierem). Biorąc pod uwagę dalszy ciąg w postaci przemowy Wojciecha o czasie, wersja W. Suriusza, potwierdzona obecnie przekazem magdeburskim, wydaje się równie dobra, jeżeli nie lepsza niż $K v$. Opowieści tej brak w redakcji krótszej tekstu, którą częstokroć w przypadku rozbieżności między $K v$ a $S$ można się posiłkować. Decyzją edytora tekst główny może zawierać jedynie jedną z lekcji (i wersji wydarzeń), ale w przypadkach takich jak tu omawiany trudno jest ją podjąć.

\section{Miejsce powstania przeróbki Vita Adalberti}

Proporcje materiału zachowanego z tekstu Nascitur sugerują, że przeróbka w naszym rękopisie (lub jej nieznany pierwowzór) pochodzić musiała z Magdeburga. Ostał się przekaz o oddaniu młodego Wojciecha na nauki do Parthenopolis ${ }^{81}$, choć zniknął z opowieści uczony i surowy Oktryk. Tekst wspomina o krzywdach, jakich doznało za Ottona II „chrześcijaństwo niemieckie” od „Polaków i innych barbarzyńskich narodów" 82 oraz poprawnie odczytuje intencje Brunona dość zawile piszącego o zniesieniu biskupstwa w Merseburgu ${ }^{83}$. Podczas drugiego pobytu męczennika w Rzymie opisane są - za Brunonem - dość licznie cuda tam dokonane oraz dicta Wojciecha: jedno - o odpowiedzialności biskupa na sądzie Bożym - w drodze do Rawenny, drugie zaś - wypowiedziane do mniszki, która znała go w młodości - w Magdeburgu ${ }^{84}$. Generalnie więc wzmianki Nascitur o Magdeburgu zostały zachowane, a mając na względzie ogólne skracanie opowieści, wydają się one w porównaniu do tekstu Brunona wręcz uwypuklone.

\section{Datowanie przeróbki}

Wśród przekształceń, jakim kompilatorzy poddali tekst, wspomnieć należy o Wojciechowym epizodzie na Monte Cassino. Podobnie jak w obydwu redakcjach pochodzących od Brunona opowieść jest tak skonstruowana, że znika podany w najstarszym żywocie wyraźny powód odejścia bohatera z klasztoru (tamtejsi benedyktyni domagali się, by mając święcenia biskupie, konsekrował budowane przez nich kościoły). Po silnie skróconym względem wersji pierwotnej wprowadzeniu montekasyńskiego interludium i napomnieniach braci, by Wojciech trzymał się zasady stabilitas loci $^{85}$ następuje komentarz: „In Bernardi ad fratres de monte: Inpossibile est hominem fideliter figere animum suum, qui non prius alicui loco perseueranter fixerit corpus suum; sive: deo seruire uellet, loco staret; quia Jeronimus: iherosolimam non uenisse, sed bene uixisse est laudabile”. Słowa Hieronima są przekształcone w stosunku do tekstu, jaki znajdujemy w innych przekazach Nascitur, ale oddają aliis verbis sens powiedzenia. Podobnie klauzula „kto chce służyć Bogu, niech pozostaje na miejscu” (czyli w klasztorze,

${ }^{81}$ Ms. Magdeb. 26, f. 313rb: „Decursa puericia ad partinopolim nouam metropolim imbuendus adducitur, ubi est confirmatus a primo archiepiscopo alberto; ex suo nomine albertum nominauit. Ludentibus aliis iste continuo studebat, ubi expletis ter tribus annis repatriauit".

${ }^{82}$ Tamże: „Eo tempore poloni et alie naciones barbare theutunicam christianitatem deuastarunt, plurimos occidentes et ecclesias subicientes".

${ }^{83}$ Tamże, f. 313rb: „episcopatum Merseburg[ensem] in Magdeb[urgensem] conflauit, uerum et beato Laurencio per uisionem ad episcopii status est commonitus, ne sibi subtraheret honorem, quem primus Octo [tj. Otto - M.S.] instituerat”.

${ }^{84}$ Tamże, f. 313vb: Hunc [?] olim Magdeb[urg] uenientem cum eum uidisset quadam monialis, qua eum iuuenem uiderat, dixit: »Alium Albertum uideo. Nam qui olim apud nos eras homo letus et iocosus, nunc autem es eo serius«. Qui grauiter suspirans respondit: »Vere domina, quicquid apud uos tunc iocando deliqui, torquet nunc grauiter animum meum«”.

${ }^{85}$ Tamże, f. 313rb: „Romam egressus [f. 313va:] ad montem Cassinum uenit, ubi a sanctis monachis monitus est, ne sic uagaret, sed magis loco staret". 
w celi). Kluczowe jest zaś to pierwsze dictum, które - niezaczerpnięte z Nascitur - jest wprowadzone jako cytat z „Bernarda” ad fratres de monte. Rzeczywiście najwcześniej znajdziemy je w szeroko rozpowszechnionej Epistola ad fratres de Monte Dei, liście do członków kartuzji Mont-Dieu napisanym przez Wilhelma z Saint Thierry ${ }^{86}$ (zm. 1148), napisanym ok. 1144-1145 r., tekście przypisywanym jednak w rękopisach od XIII w. począwszy (również tutaj) oraz w wydaniach wczesnonowożytnych Bernardowi z Clairvaux ${ }^{87}$. Dla nas cytat ten wyznacza terminus post quem przeróbki najwcześniej na połowę XII w., a jeżeli uwzględnić statystyki występowania atrybucji (Bernarda jako autora) w materiale rękopiśmiennym ${ }^{88}$ to na, wciąż szeroki, okres między XIII a XV w.

$\mathrm{Na}$ węższe datowanie pozwala natomiast naddatek w opisie zmęczenia Wojciecha grzesznością i niewiernością diecezjan, komentujący opowieść o próbie uratowania cudzołożnicy: „Verum uetus prouerbium uerificant: Non est fides in Bohemo" "89. Pochodzenie i datowanie tego proverbium nie jest jasne. Przede wszystkim jednak trzeba zauważyć, że wprowadzone jest ono jako vetus, czyli zdaniem redaktora już w chwili pisania nie było to przysłowie nowe, lecz tradycyjne. Pomijając przekazy źródłowe na okres późniejszy niż nasz rękopis datujące powstanie przysłowia ${ }^{90}$, pojawia się ono chyba najwcześniej w kronice świata pióra Dietricha Engelhusa (zm. 1434), który był m.in. studentem w Pradze i nauczycielem w Magdeburgu ${ }^{91}$. Łączył on powstanie powiedzenia o wierności czeskiej - przy czym to zapewne jest domysł samego Engelhusa - ze zdradą, jakiej dopuścił się Przemysł Ottokar I względem Filipa Szwabskiego ${ }^{92}$. Mniej więcej w tym samym czasie, w kontekście husyckim, pojawia się ono w kronice Andrzeja z Ratyzbony (ok. 1438), który komentując spór na Uniwersytecie Praskim między Czechami (w tym Janem Husem) a pozostałymi nationes, określa je jako „commune antiquum proverbium, in scholis puerorum usitatum"93. W kontekście możliwości pozyskania i utrzymania czeskiej korony znajdziemy powiedzenie w liście-poradzie z 1468 r., jaką przesłał do swego brata elektora Brandenburgii Fryderyka II Żelaznego późniejszy margrabia Albrecht III Achilles ${ }^{94}$. Również z XV w. pochodzi bawarski tropariusz (ob. British Library, Add. 27630, f. 108b), w którym po motecie Pater

${ }^{86}$ Epistola ad fratres de Monte Dei, wyd. P. Verdeyen SJ, w: Guillelmi a Sancto Theodorico opera omnia, cz. 3: Opera didactica et spiritualia, wyd. i oprac. S. Ceglar SDB, P. Verdeyen, Corpus Christianorum Continuatio Mediaevalis, t. 88, Turnhout 2003, par. 95, s. 248: „Impossibile enim est hominem fideliter figere in uno animum suum, qui non prius alicui loco perseueranter affixerit corpus suum”. Starsze wydania przypisują też ów tekst Gwigonowi Kartuzowi, piątemu przeorowi Wielkiej Kartuzji (zm. 1136); zob. Guigonis prioris quinti Maioris Carthusiae Epistola seu Tractatus ad Fratres de Monte Dei, w: Migne PL, t. 184, Paris 1862, kol. 324. Autorstwo ustalił A. Wilmart, La Préface de la 'Lettre aux Frères du Mont-Dieu', „Revue Bénédictine”, 36, 1924, nr 1-4, s. 229-247.

${ }^{87} \mathrm{O}$ zmieniającej się atrybucji w materiale rękopiśmiennych kolejnych wieków zob. J.-M. Déchanet, Les manuscrits de la Lettre aux Frères du Mont-Dieu de Guillaume de Saint-Thierry et le problème de la "préface» dans Charleville 114, „Scriptorium”, 8, 1954, nr 2, s. 236-258; M.M. Davy, Introduction, w: Un traité de la vie solitaire. Epistola ad fratres de Monte-Dei de Guillaume de Saint-Thierry, wyd. M.M. Davy, Études de philosophie médiévale, t. 29, Paris 1940, s. $29-31$.

${ }_{88}$ M.M. Davy, Introduction, s. 29-31.

${ }^{89}$ Ms. Magdeb. 26, f. 313 va.

90 Jan Dymitr Solikowski, sekretarz Zygmunta Augusta i późniejszy arcybiskup lwowski, w „Rozmowie kruszwickiej de nobilissimo regno tempore interregni post mortem Sigismundi Augusti regis X Februarii w Kruszwicy” ponad wiek po powstaniu naszego rękopisu, w 1573 r., twierdził „bo niedawno rzeczono: Nulla fides in Bohemo”; cyt. za J. Leszczyński, The Part Played by the Countries of the Crown of St. Wenceslaus and by Hungary in the Freedom Ideology of the Polish Gentry (1572-1648), w: Otázky dějin střední a východní Evropy II, red. F. Hejl, J. Kolejka, Spisy Filozofické fakulty Masarykovy univerzity v Brně, t. 203, Brno 1975, s. 44.

${ }_{91}$ O Dietrichu Engelhusie zob. H. Zinsmeyer, Engelhus, Dietrich, w: Neue Deutsche Biographie, t. 4, Berlin 1959, s. $515-516$.

${ }_{92}$ Chronicon Theodorici Engelhusii continens Res Ecclesiae et Reipublicae ab orbe condito ad ipsius usque tempora. Ex aliquot MSS. plurimum auctum emendatumque, wyd. G.W. Leibniz, w: Scriptores rerum Brunsvicensium, t. 2, Hannoverae 1710, s. 1112: „Idem [Filip Szwabski - M.S.] Occarum Ducem Bohemiae Regem fecit; qui rex factus [...] tradidit eum Ottoni; qui et ipsum [...] interfecit Bambergae, anno Domini 1208. die S. Albani. unde surrexit proverbium: Non est fides in Bohemo".

${ }_{93}$ Andreae Ratisbonensis Chronicon a Jo. Chraft praedicatore Cambensi interpolatum et usque ad an. 1490. continuatum, w: Corpus historicum Medii Aevii, t. 1, wyd. J.G. Eckhart (Eccardus), Lipsiae 1723, kol. 2128. O Andrzeju krótko H. Plechl, Andreas von Regensburg, w: Neue Deutsche Biographie, t. 1, Berlin 1953, s. 283.

${ }^{94}$ Codex diplomaticus Brandenburgensis, cz. 3, t. 1, wyd. A.F. Riedel, Berlin 1859, nr 334, s. 478: „,dann das gemeyn sprichwort lewgt selten: Non est fides in Bohemo". 
noster qui es/Ave maria znajduje się Non est fides in bohemo quando dicit bodysemo ${ }^{95}$. Ponieważ sformułowanie to wydaje się nie występować w źródłach wcześniejszych niż z pierwszej połowy XV w., sądzić trzeba, że powstało ono albo wówczas, albo niewiele wcześniej, np. w związku z wojnami husyckimi, a próbę Engelhusa powiązania przysłowia z wydarzeniami z początku XIII w. uznać należy tylko za jego domysł. W ten sposób zawęzilibyśmy datowanie naszej przeróbki jeszcze bardziej - powstalaby między drugą bądź trzecią dekadą XV w. a czasem spisania Legendarium ok. 1459 r. Wątpliwe więc, by istniejący w legendarzu tekst został in extenso skopiowany z jakiejś już skróconej podstawy, przeróbkę należy z dużym prawdopodobieństwem przypisać naszym kompilatorom.

\section{Wnioski}

Przekaz Żywota i pasji św. Brunona, wydany ostatnio w latach 30. XX w. przez H. Kauffmanna, otrzymuje „nowego" świadka. Jest to tym istotniejsze, że to drugi w ogóle przekaz rękopiśmienny tego utworu. Zawiera on zarówno naddatki, jak i fragmenty, które będąc analogiczne względem tekstu drukowanego, przekazują spójniejszą opowieść. Co warte podkreślenia, mimo że świadek magdeburski jest bez wątpienia skróconą postacią tekstu, to zawiera on również pojedyncze lekcje, które zdają się odnosić do lepszej podstawy.

Również Miracula s. Adalberti otrzymują nowego świadka rękopiśmiennego - znamy ich obecnie z zestawienia Piotra Węcowskiego ${ }^{96}$ ponad trzydzieści - zbliżonego brzmieniem do najstarszego przekazu tego tekstu (nieznanego pochodzenia rękopisu, obecnie znajdującego się Bibliotece Państwowej w Monachium, zob. wyżej). Warte podkreślenia i dalszych studiów jest to, że tekst wpisany został do Legendarium na święto translacji w XV-wiecznym Magdeburgu zgodnie z tradycją czeską, tj. 25 sierpnia. Tenże tekst uzupełniono $\mathrm{w}$ naszym rękopisie fragmentem in extenso o przeniesieniu relikwii zaczerpniętym z tzw. Cronica Boemorum, brunszwickiej epitome kroniki Kosmasa i kontynuatorów, znanej dotąd zaledwie $\mathrm{z}$ jednego rękopisu.

Przekaz żywota Nascitur w Legendarium Magdeburgense jest daleko idącymi ekscerptem oraz przeróbką i zawiera wiele skrótów i przekształceń, które wydają się negować jego wartość dla rekonstrukcji pierwotnego brzmienia utworu. $Z$ drugiej strony jednak zawiera on również fragmenty in extenso, które wydawca musi porównać zarówno z zachowanymi rękopiśmiennymi przekazami $K v$ i $W t$, jak i z drukiem W. Suriusza $(S)$. W tym sensie przekaz z XV-wiecznego Magdeburga powiększa tradycję rękopiśmienną redakcji dłuższej żywota Nascitur i jego wybrane lekcje należy włączyć do przygotowywanej edycji dzieł Brunona z Kwerfurtu. Dołącza on do wprowadzonych przeze mnie do dyskusji już uprzednio na tych łamach morawskich odpisów żywota Nascitur w obu redakcjach $(R h 2 \text { i } R h 3)^{97}$. Nowemu przekazowi nadamy - od miejsca sporządzenia świadka - sygiel $M g d$.

${ }^{95}$ F. Ludwig, Repertorium organorum recentioris et motetorum vetustissimi stili, t. 1: Catalogue Raisonné der Quellen, cz. 2: Handschriften in Mensural-Notation, wyd. L. Dittmer, Musicological Studies, t. 26, New York-Hildesheim 1978, s. 743 (tom niewydany za życia F. Ludwiga; wyd. 1 oprac. F. Gennrich w serii Summa musicae medii aevii, t. 7, Langen b. Frankfurt 1961).

${ }^{96}$ P. Węcowski, Początki Polski, s. 74-82.

${ }^{97}$ M. Sosnowski, Nowe świadectwa rękopiśmienne „Żywota drugiego św. Wojciecha” w benedyktyńskim klasztorze w Rajhradzie na Morawach, St. Źródł. 55, 2017, s. 79-100. Oczekuje jeszcze na podobną analizę i umiejscowienie w tradycji rękopiśmiennej ekscerpt redakcji dłuższej Nascitur, znajdujący się w dwóch legendarzach z terenu późnośredniowiecznej Rzeszy, tj. Jena, Thüringer Universitäts- und Landesbibliothek Jena, Ms. El. f. 26, f. 230va-232va oraz Michelstadt, Nicolaus-Matz-Bibliothek, D687, f. 333rb-340rb. Ten pierwszy został krótko scharakteryzowany w: A. Kozłowska, Leksyk dotyczący Boga w żywotach św. Wojciecha, „Studia Warmińskie” 27, 1990, s. 162-165 (charakterystyka s. 162-163; transkrypcja, s. 163-165). 


\title{
St. Adalbert of Prague and St. Bruno of Querfurt in the so-called Legendarium Magdeburgense - hagiographical texts and calendar
}

\begin{abstract}
Summary: The large Legendarium Magdeburgense $(=\mathrm{LM})$ in two volumes (Berlin, Staatsbibliothek zu Berlin, Ms. Magdeb. 26 and 138) is a hagiographical collection compiled in the Magdeburg diocese in the mid-fifteenth century. Generously catalogued by Ursula Winter, the Legendarium contains textual witnesses to a series of quite rare texts important to the history of medieval Central Europe. The article starts with the LM calendar entries for St. Adalbert of Prague, St. Bruno of Querfurt and Five Brethren. Then the attention is devoted to the LM text for the feast of translatio Adalberti, which is actually a selection from Miracula s. Adalberti (BHL 44, BHL 45), a relatively well witnessed thirteenth-century Polish collection of miracles. Some passages in the LM witness suggest that compilers used another text (either BHL 44 or BHL 38) to supply additional information. The LM witness of Miracula is also placed within the textual tradition of the this text. The author likewise focuses on the apparent use by compilers of the Cronica Boemorum (a Brunswick epitome of Cosmas of Prague) for supplying additional information to the Translatio. The attention is then given to Vita et Passio Brunonis (BHL 1471b, BHL 1472). The LM witness contains some interesting additions and reworkings which are only indicated here, without trying to judge their value vis-à-vis the existing MGH (SS 30/1) edition. On the other hand, an analysis of individual readings suggests that the LM witness, in at least certain passages, contains a better - and fuller - text than the one printed in MGH.

Most of the attention is devoted to the last text examined in this paper, a short reworking of the Vita altera of Adalbert of Prague by Bruno of Querfurt (inc. Nascitur) based on the longer redaction (BHL 38). The analysis focuses on the relative value of individual readings (notably, it confirms some readings witnessed heretofore only by an early modern pre-critical edition by Laurentius Surius vs the sole full manuscript witness used by Jadwiga Karwasińska, who edited the text in MPH s.n. IV/2 editor), as well as on the character of the reworking itself, its dating and place of production.
\end{abstract}

Notka o autorze: Miłosz Sosnowski, ur. 1980, absolwent Wydziału Historycznego UAM (2005), tam obronił również doktorat (2010) poświęcony najdawniejszym żywotom i pasjom św. Wojciecha. Stypendysta programów Erasmus (Groningen), Komitetu Badań Naukowych (doktorat), Garstka Polish-American Fellowship (Notre Dame, IN), Ministerstwa Nauki i Szkolnictwa Wyższego dla Młodych Naukowców oraz stażu podoktorskiego Narodowego Centrum Nauki FUGA. Zainteresowania badawcze koncentruje wokół hagiografii, kodykologii, paleografii łacińskiej, łaciny średniowiecznej i edytorstwa. Autor nowej edycji tzw. Pasji z Tegernsee i relacji Wiperta, pracuje nad nowym wydaniem krytycznym dzieł zebranych Brunona z Kwerfurtu.

Author: Miłosz Sosnowski (b. 1980), PhD, graduate of the Faculty of History, Adam Mickiewicz University in Poznań (2005), where he was also awarded PhD degree (2010) for the thesis devoted to the oldest hagiography of St. Adalbert of Prague; holder of scholarships: Erasmus (Groningen), the State Committee for Scientific Research (doctorate), Garstka Polish-American Fellowship (Notre Dame, IN), Ministry of Science and Higher Education for Young Researchers, and a post-doctoral funding scheme "FUGA" of the National Science Centre. His research interests include: hagiography, codicology, Latin palaeography, medieval Latin, and editorial studies. The author of a new edition of the Passio s. Adalperti martiris and Wipert's Historia de predicatione episcopi Brunonis; he is working on a new critical edition of Saint Bruno of Querfurt's collected works.

Zakład Źródłoznawstwa i Nauk Pomocniczych Historii

Instytut Historii

Uniwersytet im. Adama Mickiewicza w Poznaniu

ul. Uniwersytetu Poznańskiego 7

61-614 Poznań

e-mail: milosz.sosnowski@amu.edu.pl

\section{Bibliografia}

\section{Rękopisy}

Berlin, Staatsbibliothek zu Berlin, Ms. Magdeb. 26

Berlin, Staatsbibliothek zu Berlin, Ms. Magdeb. 138

Berlin, Staatsbibliothek zu Berlin, Ms. Boruss. 866 
Merseburg, Domstiftsbibliothek Merseburg, Cod. I, 129

Trewir, Stadtbibliothek Trier, Ms. 1999/129 $8^{\circ}$

Gdańsk, Biblioteka Gdańska PAN, Ms. Mar F 202

Uppsala, Uppsala Universitetsbiblioteket, C 520

Uppsala, Uppsala Universitetsbiblioteket, C 281

Paryż, Bibliothèque nationale de France, Lat 8432

Monachium, Bayerische Staatsbibliothek, Clm 14126

Londyn, British Library, Add. 27630

Wolfenbüttel, Niedersächsisches Landesarchiv, Staatsarchiv Wolfenbüttel, $12 \mathrm{Slg} 11 \mathrm{nr} 8$

Jena, Thüringer Universitäts- und Landesbibliothek Jena, Ms. El. f. 26

Michelstadt, Nicolaus-Matz-Bibliothek, D687

\section{Bazy danych}

Cantus Index: Catalogue of Chant Texts and Melodies $<$ http://cantusindex.org $>$

\section{Źródła drukowane}

Andreae Ratisbonensis Chronicon a Jo. Chraft praedicatore Cambensi interpolatum et usque ad an. 1490 continuatum, w: Corpus historicum Medii Aevii, t. 1, wyd. J.G. Eckhart (Eccardus), Lipsiae 1723, kol. 1931-2176

Antiphonale Romanum secundum liturgiam horarum ordinemque cantus officii dispositum a Solesmensibus monachis praeparatum, t. 2: Liber Hymnarius cum invitatoriis et aliquibus responsoriis, Solesmes 1983

Chronicon Theodorici Engelhusii continens Res Ecclesiae et Reipublicae ab orbe condito ad ipsius usque tempora. Ex aliquot MSS. plurimum auctum emendatumque, wyd. G.W. Leibniz, w: Scriptores rerum Brunsvicensium, t. 2, Hannoverae 1710, s. $977-1143$

Codex diplomaticus Brandenburgensis, cz. 3, t. 1, wyd. A.F. Riedel, Berlin 1859, nr 334

Cosmae Pragensis Chronica Boemorum, wyd. B. Bretholz, w: MGH, Scriptores rerum Germanicarum, Nova Series, t. 2, Berolini 1923

De probatis sanctorum historiis [etc.], t. 2 (martii et aprilis), wyd. L. Surius, Coloniae Agrippinae 1571

Epistola ad fratres de Monte Dei, wyd. P. Verdeyen SJ, w: Guillelmi a Sancto Theodorico opera omnia, cz. 3: Opera didactica et spiritualia, wyd. i oprac. S. Ceglar SDB, P. Verdeyen, Corpus Christianorum Continuatio Mediaevalis, t. 88, Turnhout 2003, s. 223-289

Gesta archiepiscoporum Magdeburgensium, wyd. W. Schum, w: MGH SS, t. 14, Hannoverae 1883, s. 361-486

Gesta episcoporum Halberstadensium, wyd. L. Weiland, w: MGH SS, t. 23, Hannoverae 1874, s. 73-123

Guigonis prioris quinti Maioris Carthusiae Epistola seu Tractatus ad Fratres de Monte Dei, w: Migne PL, t. 184, Paris 1862 , kol. 307-364

Miracula sancti Adalberti martiris, wyd. G.H. Pertz, w: MGH SS, t. 4, Hannoverae 1841, s. 613-616

Miracula sancti Adalberti, wyd. W. Kętrzyński, w: MPH, t. 4, Lwów 1884, s. 221-238

Die Reichschronik des Annalista Saxo, wyd. K. Nass, w: MGH SS, t. 37, Hannover 2006

S. Adalberti Pragensis episcopi et martyris vita prior, wyd. J. Karwasińska, w: MPH s.n., t. 4, cz. 1, Warszawa 1962

S. Adalberti Pragensis episcopi et martyris vita altera auctore Brunone Querfurtensi, wyd. J. Karwasińska, w: MPH s.n., t. 4, cz. 2, Warszawa 1969

Thietmari Merseburgensis episcopi Chronicon, wyd. R. Holtzmann, w: MGH, Scriptores rerum Germanicarum, Nova Series, t. 9, Berolini 1935

Die Totenbücher von Merseburg, Magdeburg und Lüneburg, wyd. G. Althoff, J. Wollasch, w: MGH, Libri memoriales et Necrologia, Nova Series, t. 2, Hannover 1983

Vita et passio sancti Brunonis episcopi et martyris Querfordensis, wyd. H. Kauffmann, w: MGH SS, t. 30, cz. 2, Lipsiae 1934, s. 1350-1367

\section{Opracowania}

Albrecht S., Drei neue Handschriften des sog. Chronicon hungarico-polonicum, St. Źródł., 53, 2015, s. 111-121

Albrecht S., Three New Manuscripts of the so Called [sic!] Chronicon hungaro-polonicum, w: Hungaro-Polonica. Young Scholars on Medieval Polish-Hungarian Relations, red. D. Bagi, G. Barabás, Z. Máté, Pécs 2016, s. $119-141$

Bláhová M., Cronica Boemorum auctore canonico S. Blasii Brunsvicensi, w: Encyclopedia of the Medieval Chronicle, red. G. Dunphy, Leiden-Boston $2010<\mathrm{http}$ ://referenceworks.brillonline.com/entries/encyclopedia-of-themedieval-chronicle/cronica-boemorum-auctore-canonico-s-blasii-brunsvicensi-SIM_001041 > [dostęp: 10.11.2017] 
Corpus Antiphonalium Officii, red. R.-J. Hesbert, t. 1-6, Roma 1963-1979

Danielski W., Kult św. Wojciecha na ziemiach polskich $w$ świetle przedtrydenckich ksiag liturgicznych, przyg. do dr. i wstęp J.J. Kopeć CP, Lublin 1997

Davy M.M., Introduction, w: Un traité de la vie solitaire. Epistola ad fratres de Monte-Dei de Guillaume de Saint-Thierry, wyd. M.M. Davy, Études de philosophie médiévale, t. 29, Paris 1940, s. 11-185

Déchanet J.-M., Les manuscrits de la Lettre aux Frères du Mont-Dieu de Guillaume de Saint-Thierry et le problème de la "préface» dans Charleville 114, „Scriptorium”, 8, 1954, $\mathrm{nr}$ 2, s. 236-258

Delehaye H., Étude sur le légendier romain. Les saints de novembre et de décembre, Subsidia Hagiographica, t. 23, Brussels 1936

Drelicharz W., Idea zjednoczenia królestwa w średniowiecznym dziejopisarstwie polskim, Monografie Towarzystwa Naukowego Societas Vistulana, t. 1, Kraków 2012

Das Erzbistum Magdeburg, t. 1: Das Domstift St. Moritz in Magdeburg, oprac. G. Wentz, G. Schwineköper, Germania Sacra AF, t. 1, cz. 1, Berlin-New York 1972

Grotefend H., Zeitrechnung des Deutschen Mittelalters und der Neuzeit, t. 2, cz. 1, Hannover 1892

Holder-Egger O., Über die Braunschweiger und Sächsische Fürstenchronik und verwandte Quellen, „Neues Archiv", 17, 1892, s. 159-184

Hosák L., Šrámek R., Mistní jména na Moravě a ve Slezsku, t. 2, Praha 1980

Jiroušková L., Der heilige Wikingerkönig Olav Haraldsson und sein hagiographisches Dossier. Text und Kontext der Passio Olavi (mit kritischer Edition), t. 1, Mittellateinische Studien und Texte, t. 46, Leiden-Boston 2014

Kade R., [wstęp do wyd.] Brunonis Vita Quinque Fratrum, w: MGH SS, t. 15, cz. 1, Hannoverae 1888, s. 709-716

Kessel E., Die Magdeburger Geschichtschreibung im Mittelalter bis zum Ausgang des 12. Jahrhunderts, „Sachsen und Anhalt", 7, 1931, s. 110-183

Kozłowska A., Leksyk dotyczacy Boga w żywotach św. Wojciecha, „Studia Warmińskie” 27, 1990, s. 157-165

Leonavičiūte I., Magdeburgo arkivyskupu darbai. Šv. Brunono Kverfurtiečio Darbu knygos (Liber Gestorum) klausimas, „Lietuvos istorijos studijos”, 35, 2015, s. 9-23

Leszczyński J., The Part Played by the Countries of the Crown of St. Wenceslaus and by Hungary in the Freedom Ideology of the Polish Gentry (1572-1648), w: Otázky dějin středni a východni Evropy II, red. F. Hejl, J. Kolejka, Spisy Filozofické fakulty Masarykovy univerzity v Brně, t. 203, Brno 1975

Ludwig F., Repertorium organorum recentioris et motetorum vetustissimi stili, t. 1: Catalogue Raisonné der Quellen, cz. 2: Handschriften in Mensural-Notation, wyd. L. Dittmer, Musicological Studies, t. 26, New York-Hildesheim 1978

Die Manuscripta Magdeburgica der Staatsbibliothek zu Berlin Preussischer Kulturbesitz, t. 1, oprac. U. Winter, Wiesbaden 2001; t. 2, oprac. U. Winter, K. Heydeck, Wiesbaden 2004

Mentzel-Reuters A., Literaturbericht Handschriftenkataloge, „Deutsches Archiv”, 60, 2004, nr 1, s. 201-232

Nass K., Wolfenbütteler Funde, „Deutsches Archiv für Erforschung des Mittelalters”, 49, 1993, nr 1, s. 165-169

Ochałówna C., Bitwa grunwaldzka w poezji polsko-łacińskiej XV wieku, „Małopolskie Studia Historyczne”, 3, 1960, nr 1-2, s. 81-106

Schmidt P.G., Lateinische Literatur Magdeburgs von ottonischer zu staufischer Zeit, w: Der Magdeburger Dom. Ottonische Gründung und staufischer Neubau, red. E. Ullmann, Lepzig 1989, s. 220-225

Sosnowski M., Nowe świadectwa rękopiśmienne „Żywota drugiego św. Wojciecha” w benedyktyńskim klasztorze w Rajhradzie na Morawach, St. Źródł. 55, 2017, s. 79-100.

Sosnowski M., Studia nad wczesnymi żywotami św. Wojciecha. Tradycja rękopiśmienna i polemika środowisk, Poznań 2013

Voigt H.G., Eine neuerdings wiederentdeckte mittelalterliche Lebensbeschreibung des Preußenmissionars Brun von Querfurt, „Sachsen und Anhalt”, 3, 1927, s. 87-134

Węcowski P., Poczatki Polski w pamięci historycznej późnego średniowiecza, Monografie Towarzystwa Naukowego Societas Vistulana, t. 2, Kraków 2014

Wilmart A., La Préface de la 'Lettre aux Frères du Mont-Dieu', „Revue Bénédictine”, 36, 1924, nr 1-4, s. 229-247

Winter U., Das Legendarium Magdeburgense in der Staatsbibliothek zu Berlin - Preussischer Kulturbesitz (Mss. Magdeb. 26 und 138), w: Scrinium Berolinense. Tilo Brandis zum 65. Geburtstag, t. 1, red. P.J. Becker, E. Bliembach, H. Nickel, R. Schipke, G. Staccioli, Berlin 2000, s. 320-327

Zwierlein O., Die Urfassungen der Martyria Polycarpi et Pionii und das Corpus Polycarpianum, t. 1, Berlin-Boston 2014 